\title{
An Inside Look into Biological Miniatures: Molecular Mechanisms of Viroids
}

\author{
Srividhya Venkataraman, Uzma Badar, Erum Shoeb (D), Ghyda Hashim, Mounir AbouHaidar and \\ Kathleen Hefferon *
}

check for updates

Citation: Venkataraman, S.; Badar, U.; Shoeb, E.; Hashim, G.; AbouHaidar, M.; Hefferon, K. An Inside Look into Biological Miniatures: Molecular Mechanisms of Viroids. Int. J. Mol. Sci. 2021, 22, 2795. https://doi.org/10.3390/ijms22062795

Academic Editor: Teruo Sano

Received: 13 December 2020

Accepted: 3 March 2021

Published: 10 March 2021

Publisher's Note: MDPI stays neutral with regard to jurisdictional claims in published maps and institutional affiliations.

Copyright: (c) 2021 by the authors. Licensee MDPI, Basel, Switzerland This article is an open access article distributed under the terms and conditions of the Creative Commons Attribution (CC BY) license (https:// creativecommons.org/licenses/by/ $4.0 /)$.
Cell and System Biology, University of Toronto, Toronto, ON M5S 3B2, Canada; byokem@hotmail.com (S.V.); uzmabadar.ca@gmail.com (U.B.); erumsh@uok.edu.pk (E.S.); ghydaHashim@cmail.carlton.ca (G.H.); mounir.abouhaid@utoronto.ca (M.A.)

* Correspondence: kathleen.hefferon@alumni.utoronto.ca

\begin{abstract}
Viroids are tiny single-stranded circular RNA pathogens that infect plants. Viroids do not encode any proteins, yet cause an assortment of symptoms. The following review describes viroid classification, molecular biology and spread. The review also discusses viroid pathogenesis, host interactions and detection. The review concludes with a description of future prospects in viroid research.
\end{abstract}

Keywords: viroids; replication; rolling circle; pathogenicity; trafficking; viroid-host interactions; gene silencing; evolution; classification; identification

\section{Introduction}

Viroids are one of the most inscrutable single-stranded, structured, circular RNA pathogens of plants as well as the smallest infectious agents ever known [1,2]. Despite being incapable of coding for any proteins, viroids affect susceptible plant hosts with visually discernible symptoms resembling those induced by several plant viruses. Diener, 1967, 1971 [3,4] discovered and exemplified the Potato Spindle Tuber Viroid (PSTVd), the first viroid ever known. He coined the term "viroid" to represent this diminutive, naked, protein-free, circular RNA plant pathogen [4-6]. This conceptualization of the viroid was further substantiated by Sänger, 1972 [7] as well as Semancik and Weathers, 1972 [8], who identified the citrus exocortis viroid (CEVd) that is responsible for causing the citrus exocortis disease. Another viroid, the chrysanthemum stunt viroid (CSVd) is also one of the viroids initially identified $[9,10]$. Following the initial identification of the PSTVd, numerous other viroids have been discovered [11]. There are currently about 32 recognized species as well as eight putative species of viroids [12]. Some of the most recently identified viroids include the columnea latent viroid (CLVd) and the pepper chat fruit viroid (PCFVd) infecting pepper in Vietnam identified by RNA-seq [13].

Viroids are covalently closed circular RNA molecules with rigid rod-like secondary structure ranging in size between approximately 250 to 400 nucleotides [14,15]. Viroids undergo autonomous replication and occur as circular and linear forms containing a high degree of base pairing while parasitizing the host transcriptional machinery [2,15]. Viroids are totally dependent on host cellular RNA polymerases and processing enzymes for their replication. They are categorized into two families: the Avsunviroidae (type species, Avocado sunblotch viroid ASBVd) and the Pospiviroidae (type species, PSTVd) [16-20]. Unlike viruses, viroids do not require to be encapsidated for propagation among host plants. Viroid RNA moves from infected cells into adjacent cells via plasmodesmata and then through the phloem to distant sink organs of its host plant $[18,21]$. Transmittance of viroids occurs through grafting, mechanical injury, pollen, seed and/or insects [21].

Viroids cause mild to severe diseases in economically significant crops including both herbaceous and woody plants such as for instance, apple, avocado, coconut, grapevine, 
hop, peach, potato and tomato [2,22]. Symptoms induced by viroids range from mild to severe, some causing even debilitating, lethal infections. Symptoms depend to a large extent on the strain of the viroid (its nucleotide sequence), the nature of the susceptible host (genotype), environmental conditions as well as the type and the severity of the disease they induce [21]. Viroids elicit disease symptoms by interacting directly with host factors, although the precise molecular mechanisms involved are yet to be completely understood. Increasing evidence on the viroid-derived small RNAs and their involvement in RNA silencing pathways has shed light into the molecular machinery involved in viroid pathogenicity.

It is very intriguing that viroids are able to cause several destructive diseases in their host plants while being diminutive infectious molecules. This means that the limited genetic information that they carry is sufficient to induce systemic infection in susceptible plants [19]. Considering that they are non-coding RNAs, viroids rely on their own genome information, covalently closed circular RNA composition and structure imposed by their very nucleotide sequences to replicate and induce diseases in their respective host plants [23-28]. Thus, they can be considered as "abnormal" regulatory RNAs and not operative messenger RNAs [4]. The viroid disease symptoms result from a complex interaction between the pathogenic viroid RNA and the plant genome and the ensuing changes within the host cellular machinery that translate into alterations of the physiology of the host plant [20].

Viroids negatively impact the world's economy by causing the destruction of susceptible crop plants and cause unbridled spread of infection leading to several important plant diseases. A majority of the crop devastation associated with infection by plant viruses [29] largely applies to viroids. Hence, there is a compelling need to study the molecular biology of viroids as well as their complex interactions with their hosts and the insect species which are involved in their transmission to design viable intervention strategies towards improving crop security.

With biotechnological advancements such as microarrays [30] and next-generation sequencing technologies (NGS) [13], novel viroids, their variants and novel host-pathogen interactions are being identified in diverse geographical regions. For instance, RNA-seq technology and computational algorithms have been employed to discover the grapevine latent viroid (GLVd) and the grapevine hammerhead viroid-like RNA (GHVd-like RNA) in grapevines and deep sequencing has been useful in identifying the apple hammerhead viroid-like RNA (AHVd-like RNA) in apples [31,32]. Additionally, grapevines in India have been recently shown to host viroids such as Australian grapevine viroid (AGVd), hop stunt viroid (HSVd) and the grapevine yellow speckle viroid 1 (GYSVd-1) indicating wide geographical distribution of viroids [33,34]. NGS studies have already been executed for some members of the Pospiviroidae family such as citrus bark cracking viroid (CBCVd) [35], HSVd [36], hop latent viroid (HLVd) [37] and the PSTVd [38].

Several contemporary reviews have addressed many of the viroid characteristics such as their structure, replication, trafficking and disease determining modes in host plants [15,20-22,39-41]. Over the last decade, many technological approaches like biochemistry, molecular biology, computational biology and modern sequencing technologies are increasingly being employed to understand viroid biology, viroid pathogenicity and viroidhost interactions. However, a comprehensive summary of current literature elucidating viroid molecular biology, pathogenicity, trafficking, transmission strategies, viroid-insectplant interactions and viroid detection technologies in the light of the recent technological breakthroughs is lacking. Therefore, the major objective of this review is to highlight the above molecular characteristics of these biological miniatures in the context of the latest biotechnological advancements. Finally, the review closes with an insightful discussion regarding the taxonomy and evolution of viroids in the light of recent discoveries in the viroid field. This review is only focused on discussing the molecular mechanisms involved in viroid infections and does not address diseases caused by viroids which could be a subject, albeit a vast one, for another review. 


\section{Biology of Viroids}

Discovered in 1971, viroids are the smallest and simplest plant pathogens, ranging from 250 to 400 nucleotides of RNA, and are known as "living fossils of the hypothetical RNA World" [42]. These autonomous infectious agents are devoid of any protein coding capability and can survive without any protected membrane around their single-stranded, circular RNA genomes. Viroids can not only fight the host cellular mechanisms of RNA degradation but can also successfully replicate themselves using factors from the host plant, resulting in their spread throughout the plants and disease symptoms [14]. Angiosperms are reported as the only natural hosts of viroids [43].

The processes involved in viroid infection after entry into cells includes [15,24,27,44].

(a) entry into a subcellular organelle (chloroplast or nucleus according to the type of viroid),

(b) rolling circle replication within chloroplast or nucleus,

(c) release out of the cell following replication,

(d) transport into nearby cells,

(e) entry into and within the phloem,

(f) invasion of nonvascular cells from the phloem and,

(g) repeat of the infection cycle.

The viroid genome does not encode for any protein, but instead spreads throughout the plant by recruiting host proteins using their own RNA folded structure. Functional motifs within the RNA structure are required for cellular trafficking in host plants [45]. The nucleotide sequence of the viroid is also important for interacting with the genome of the host. RNA-directed DNA methylation (RdDM) has been reported in viroid-infected plants $[46,47]$ and examples of silencing of functional genes by individual viroid derived small RNA (vd-sRNA) have been reported [48-50].

Viroids replicate in host plants using host RNA polymerases that interact with the viroid RNA template, resulting in a higher than usual rate of errors in comparison to DNA replication. Hence, a given replicating viroid produces several mutants along with its original sequence, the mix being termed quasispecies [51,52]. These closely related quasispecies exhibit vast variation in their host invading capability, demonstrating that the property of infecting the host depends mainly on nucleotide sequence of the viroids. Furthermore, the cause of variability in symptoms of viroid infections also depends on viroid-host-environment interactions.

The cytopathology of family Pospiviroidae include cavity formation within the cell membrane and cell wall thickening [53]. Peach latent mosaic viroid (PLMVd) infections were demonstrated to lead to chloroplast malformations [54]. Tracking viroid cytopathic effects represents a promising approach to understand the links between disturbances at the cellular level and macroscopic symptoms $[55,56]$.

Viroids are distinguished on the basis of their transmission within host plants following either vertical or horizontal patterns [57]. Pollen and ovules of a plant are responsible for transmission of viroid infections from parental plants through seeds and then seedlings to the next generation in the vertical mode of transmission; an example is the PSTVd. During horizontal transmission (an example is Tomato planta macho viroid), infection is transmitted to the next generation through the ovaries of a plant getting infected from physical contact of another plant without fertilization [58]. The degree of vertical and/or horizontal transmission of viroids depends on the molecular interaction of the viroid with the host plant, resulting in recognition and elimination of viroid RNA in the male gametophyte [59].

Mediator (MED) is a conserved protein complex in plants. According to recent reports, MED subunits exhibited differential expression patterns against different viroids, suggesting that the connection of the MED subunit transcriptional reprogramming with viroid infections resulted in differences in symptom development for different viroids [60].

\section{Taxonomy and Classification of Viroids}

According to the International Committee on Virus Taxonomy (ICTV), "rules concerned with the classification of viruses shall also apply to the classification of viroids" [61]. 
Viroid classification is based on secondary structure. Currently 32 species of viroids are recognized by ICTV. The observation of quasispecies poses an important taxonomic question for considering related viroid variants as of the same or different species. Less than $90 \%$ genome sequence identity was the first criterion taken into consideration and to be accompanied later by the possession of another distinguishing biological feature, in order to classify any two viroid species as distinct, as per the ICTV classification requirements [17]. Table 1 highlights the molecular criteria that are considered in the classification of viroids [2].

Table 1. Molecular features of viroids considered for classification.

\begin{tabular}{ccc}
\hline Molecular Characteristics & Family Avsunviroidae & Family Pospiviroidae \\
\hline Viroid structure & Y-shaped or branched & Rod-like \\
\hline Structural/Functional domains & Not applicable & $\begin{array}{c}\text { Terminal left (TL), Pathogenicity (P), Central } \\
\text { (C), Variable (V) and Terminal right (TR) }\end{array}$ \\
\hline Ribozyme function & Yes & No \\
\hline Site of replication within the host & Chloroplast & Asymmetric rolling circle mechanism \\
\hline Mode of replication & Symmetric rolling circle mechanism & RNA-templated RNA transcription \\
DNA-dependent \\
RNA polymerase II
\end{tabular}

(Adapted from Adkar-Purushothama and Perreault, 2019 [2]).

Viroids are divided into two families: Avsunviroidae and Pospiviroidae [2,15,24,43,44,62,63] (Table 2). Family Avsunviroidae contain three genera with members resembling ASBVd with branched secondary structures chloroplast-based symmetric rolling-circle replication mechanism and most importantly having ribozyme activities. On the other hand, family Pospiviroidae with five genera has PSTVd-like members, consisting of five major domains as secondary structures, asymmetric rolling-circle replication that occurs in the nucleus and are commonly devoid of any ribozyme activities. Avsunviroidae infect only dicotyledonous plants, both herbaceous and woody [20] while viroids of the family Pospiviroidae can infect both monocot and dicot plants [64].

Table 2. Classification of viroids and viroid-like RNAs. Type member of each genus is indicated in bold. Viroid and viroid-like RNAs unassigned are represented by * symbol. (Adapted from Adkar-Purushothama and Perreault, 2019 [2]).

\begin{tabular}{ccc}
\hline Family & Genus & Species \\
\hline Avsunviroidae & Avsunviroid & Avocado sun blotch viroid \\
\hline Pelamoviroid & $\begin{array}{c}\text { Peach latent mosaic viroid } \\
\text { Chrysanthemum chlorotic mottle viroid }\end{array}$ \\
& Elaviroid & Eggplant latent viroid \\
& Grapevine hammerhead viroid-like RNA * \\
& Apple hammerhead viroid-like RNA * \\
\hline & Potato spindle tuber viroid \\
& Tomato apical stunt viroid \\
& Tomato chlorotic dwarf viroid \\
& Tomato planta macho viroid \\
& Columnea latent viroid \\
& Citrus exocortis viroid \\
& Chrysanthemum stunt viroid \\
& Pepper chat fruit viroid \\
& Iresine viroid I \\
& Portulaca latent viroid *
\end{tabular}


Table 2. Cont.

\begin{tabular}{|c|c|c|}
\hline Family & Genus & Species \\
\hline & Hostuviroid & $\begin{array}{l}\text { Hop stunt viroid } \\
\text { Dahlia latent viroid }\end{array}$ \\
\hline & Cocadviroid & $\begin{array}{c}\text { Coconut cadang-cadang viroid } \\
\text { Coconut tinangaja viroid } \\
\text { Citrus bark cracking viroid } \\
\text { Hop latent viroid }\end{array}$ \\
\hline & Apscaviroid & $\begin{array}{c}\text { Apple scar skin viroid } \\
\text { Apple dimple fruit viroid } \\
\text { Pear blister canker viroid } \\
\text { Citrus bent leaf viroid } \\
\text { Citrus dwarfing viroid } \\
\text { Citrus viroid V } \\
\text { Citrus viroid VI } \\
\text { Citrus viroid OS } \\
\text { Australian grapevine viroid } \\
\text { Grapevine yellow speckle viroid } 1 \\
\text { Grapevine yellow speckle viroid } 2 \\
\text { Apple fruit crinkle viroid * } \\
\text { Grapevine yellow speckle viroid } 3 \text { * } \\
\text { Grapevine latent viroid * } \\
\text { Persimmon latent viroid * } \\
\text { Persimmon viroid } 2 *\end{array}$ \\
\hline & Coleviroid & $\begin{array}{l}\text { Coleus blumei viroid } 1 \\
\text { Coleus blumei viroid } 2 \\
\text { Coleus blumei viroid } 3 \\
\text { Coleus blumei viroid } 4 \text { * } \\
\text { Coleus blumei viroid } 5 * \\
\text { Coleus blumei viroid } 6 *\end{array}$ \\
\hline
\end{tabular}

The three genera of family Avsunviroidae are: Avsunviroid, Pelamoviroid, and Elaviroid. Species in the genus Avsunviroid, have a low content of $G+C$ with rod-like secondary structure. Species of genus pelamoviroids have high $G+C$ content with branched secondary structures. The single species of genus elaviroid have intermediate structural properties that are between those of the other two genera of the family [56].

Five genera of family Pospiviroidae are: Apscaviroid, Cocadviroid, Coleviroid, Hostuviroid and Pospiviroid. Each genus has a characteristic central conserved region (CCR) with least modifications, while the species of genera apscaviroids and pospiviroids have terminal conserved regions (TCR) and those of cocadviroids and hostuviroids have terminal conserved hairpins (TCH). The Coleviroid species are devoid of TCR and TCH [65]. Figure 1 exemplifies the various structures adopted by these viroids [66]. 
A

Family: Pospiviroidae

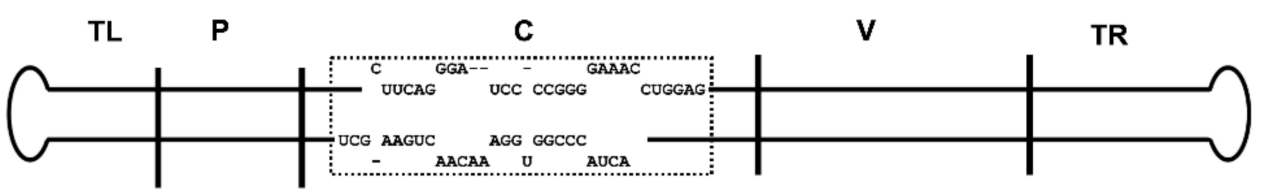

B

Family: Avsunviroidae

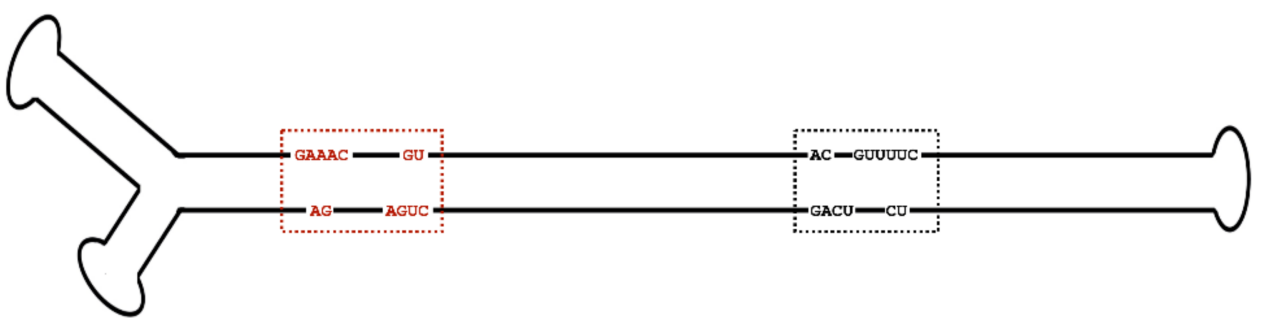

C

HSVd: CCR and non-functional hammerhead-like domain

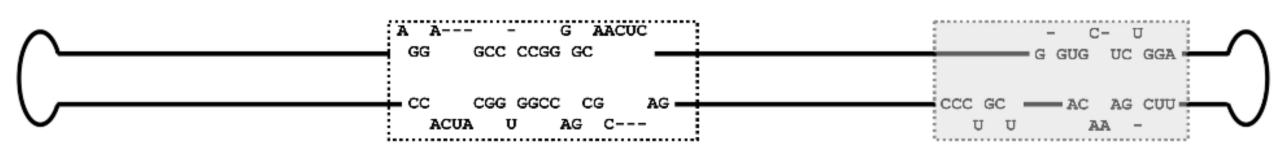

Figure 1. Structural differences among viroids. (Adapted from Adkar-Purushothama and Perreault, 2020 [66]). Primary and secondary structural characteristics considered for classification of viroids: (A) the PSTVd rod-like secondary structure comprising five functional domains is shown: the Terminal left (TL), Pathogenicity (P), Central (C), Variable (V) and Terminal right (TR) domains are separated by solid vertical lines. The nucleotide sequence of the central conserved region (CCR), a typical feature of the family, Pospiviroidae is shown within the box. (B) The ASBVd branched secondary structure is shown. Boxes represent the conserved nucleotides of the catalytic core within the hammerhead, a typical feature of the Avsunviroidae. The red and black boxes, respectively, indicate the hammerhead self-cleaving structures formed within the (+) and (-) strands. (C) The HSVd rod-like secondary structure is shown. The black-colored box represents the CCR while the shadowed box represents the non-functional hammerhead-like domain.

\section{Viroid Structure and Replication}

PSTVd was the first viroid structure ever determined [4]; electron microscopy revealed that PSTV forms a secondary structure, and this was confirmed in 1978 [67,68].

Most of the known viroid species belong to the Pospiviroidae family, named after the type member, the PSTVd [15]. The Pospiviroidae adopt circular, internally base-paired, rodlike structures and their genomes consist of five distinct domains: The terminal left (TL), terminal right $(\mathrm{TR})$, central $(\mathrm{C})$, pathogenic $(\mathrm{P})$ and variable $(\mathrm{V})$ domains. The pathogenicity domain possesses relatively low thermodynamic stability (or pre-melting) due to the presence of an oligopyrimidine stretch in most of the Pospiviroidae, the V domain is the most variable region, and the $C$ domain is most highly conserved.

To date, only four viroids have been identified as belonging to the Avsunviroidae family, named after ASBVd. These types of viroids lack a conserved central region but retain rod-like and branched regions like Pospiviroidae viroids. However, unlike Pospiviroidae viroids, Avsunviriodae members can form hammerhead ribozyme motifs in both polarities which mediate cleavage of their replication intermediates, while RNA cleavage within Pospiviroidae family members takes place using host enzymes [15].

The replicative mechanism of viroids operates through two alternative pathways depending in whether it is mediated by one or two rolling circles [21]. The first pathway is called asymmetric, typical of Pospiviroidae and is mediated by a single rolling circle wherein the incoming circular positive sense viroid RNA genome is repeatedly transcribed 
to form multimeric, linear (-) strands. Thereupon, in the next step, these (-) sense concatemers serve as templates for the synthesis of multimeric, linear $(+)$ strand concatemers which subsequently are cleaved into monomeric $(+)$ circles. In the alternate second pathway called symmetric, typical of Avsunviroidae (Figure 2) [69], replication operates through two rolling circles wherein the multimeric linear $(-)$ strands generated from the $(+)$ sense RNA genome of the viroid undergo cleavage and ligation to generate circular (-) strand RNA monomers. These (-) strand circles then act as templates for the subsequent generation of linear, multimeric $(+)$ strands which then cleave into $(+)$ sense monomer genomes.

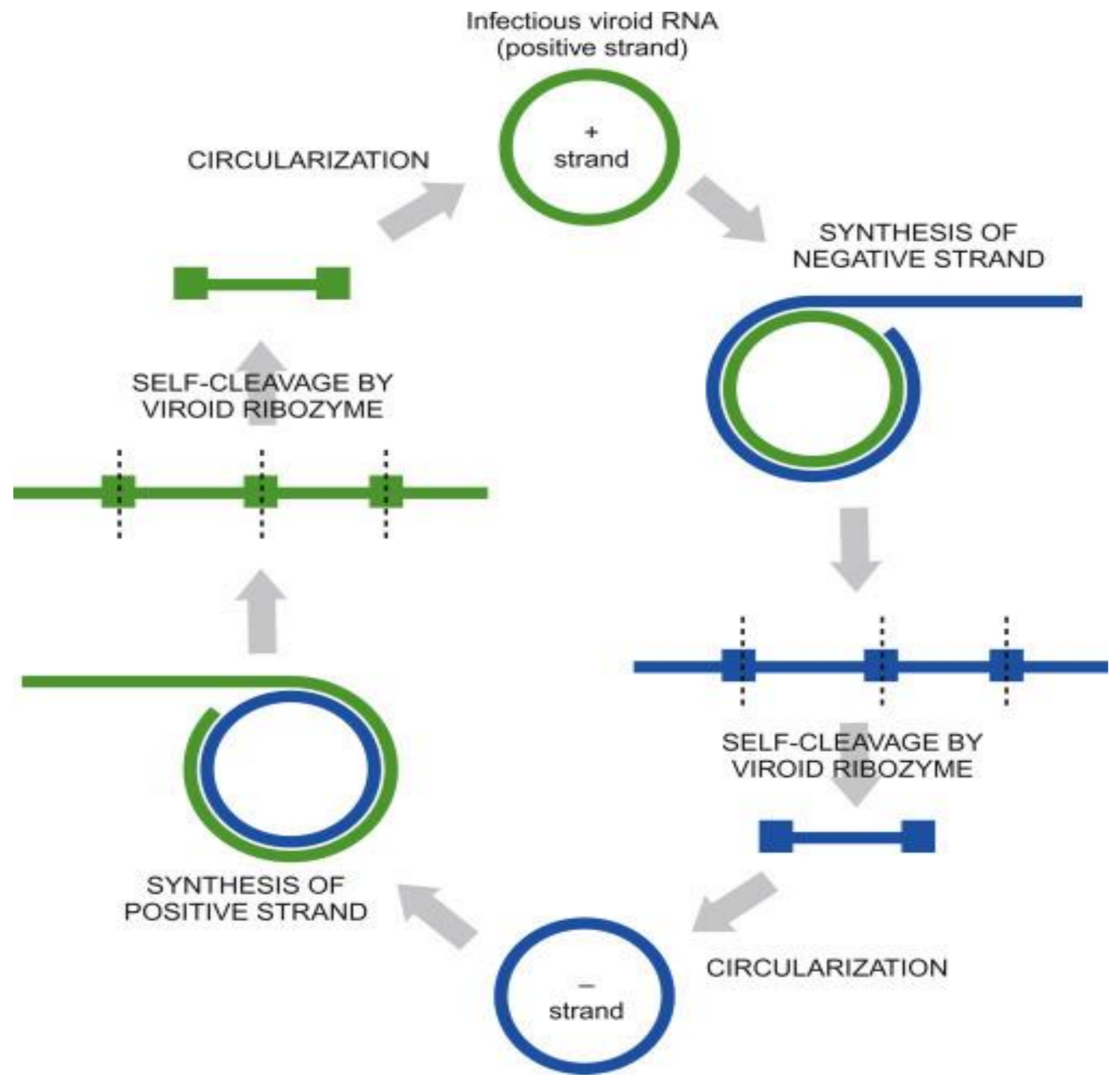

Figure 2. Rolling circle model for Avsunviroid replication (adapted from Clark et al., 2019 [69]).

For PSTVd, the type member of Pospiviroidae, the absence of circular monomeric $(-)$ sense RNA in plants after natural infection supports the asymmetric model of replication $[70,71]$. On the other hand, for the ASBVd (the type member of Avsunviroidae) it has been shown by in vitro studies that both $(+)$ and $(-)$ dimeric RNAs are able to self-cleave (Figure 2), thus supporting the model of symmetric replication [72,73]. Additionally, it has been observed in ASBVd-infected avocado that both monomeric circular $(+)$ and $(-)$ strands occur in multistranded complexes substantiating that ASBVd replication occurs through two rolling circles [74,75].

Members of the Pospiviriodae replicate in the nucleus [76]. Replication is initiated from a precise site, thus implying the possibility of existing viroid promoters. The processes of cleavage and ligation in the Pospiviroidae family are thought to be catalyzed by a host enzyme similar to RNase III and an RNA ligase that supports the circularization process. The two enzymes can circularize the viroid by covalent fusion of both $5^{\prime}$ and $3^{\prime}$ termini. 
Researchers have not identified whether chloroplastic RNA ligase is necessary for the circulation process or whether autocatalysis takes place.

Avsunviroidae replication takes place within chloroplasts. The mode of entry and exit into the chloroplasts is still debatable as it is not well identified [76].

The accumulation of Avsunviriodae (+) and (-) strands in the chloroplast indicates the involvement of enzymatic machinery of the chloroplast in the replication cycle; in contrast, accumulation of the Pospiviroidea RNA strands in the nucleus suggests the involvement of nuclear RNA polymerase and other cellular enzymes in their replication cycle [21].

\section{Movement and Systemic Trafficking of Viroid RNAs}

Viroids are subviral pathogens that cause infection in several crop plants, leading to considerable yield losses [77]. Within the plants, viroid RNA moves to adjacent cells through plasmodesmata and, via the phloem, to distant sink organs [23]. Viroids have recently emerged as ideal model systems to study RNA transport within and between cells [23]. Conventional viroid infection of a host plant comprises a series of coordinated steps that involve both intracellular movement and intercellular movement.

Mutational experiments of viroids have identified RNA motifs within the viroid genome that are important for cell-to-cell trafficking. For PSTVd, this consists of 27 RNA loop motifs separated by short helices $[74,78,79]$. An RNA motif of PSTVd was found to be essential for trafficking from bundle-sheath cells into mesophyll cells when the viroid was exiting in the phloem of young tobacco leaves [26]. Whereas in Nicotiana benthamiana, a different RNA motif was required for movement of PSTVd from the bundle sheath cells into the phloem [80]. Furthermore, 11 out of 27 loops of PSTVd RNA motifs are important for cell-to-cell movement and intercellular spread and these RNA motifs could also be involved in the trafficking of viral and cellular RNAs [81]. Loop 19 was identified for viroid movement from palisade to spongy mesophyll cell of N. benthamiana [82], while loop 6 had previously been shown to be essential for palisade-to-spongy mesophyll trafficking [83]. These studies enlighten the potential functions of plasmodesmata (PD), as different RNA motifs are required to transit PD at different cell-to-cell interfaces. It was also identified that different RNA motifs can be used to transit across the same cellular interface.

Various experiments have been performed to identify viroid RNA movement. Microinjection experiments using infectious RNA transcripts and labeled with the fluorescent dye TOTO-1 iodide have shown that PSTVd can move rapidly from cell to cell via the plasmodesmata in tobacco mesophyll cells [84]. It was also observed that PSTVd RNA accumulates in the nuclei of both the injected cell and neighboring cells. Using dot-blot hybridization to monitor PSTVd distribution in infected tomato seedlings, it was found that the movement pattern of PSTVd was indistinguishable from that of most plant viruses at the whole plant level [84].

\section{Seed, Pollen and Insect Transmission of Viroids}

Most of the viroids are disseminated through human activities during planting and through trade in materials of the plants, such as seeds and tissue culture stocks, but some viroids have evolved specific mechanisms exploiting the plants' processes of reproduction and are transmitted via seed and/or pollen [85-87]. Pollen is an important breeding biological tool of germplasm naturally found to be associated with number of viroids, known as being pollen-transmitted [88]. Transmission of viroids by pollen can be horizontal, contaminating a fertilized flower, or can be vertical which is more common when infected pollen fertilize and infect the resulting seed [89]. Pollen transmitted PSTVd and PCFVd have been detected in tomato (Solanum lycopersicum) crops [90].

The rate at which infected seeds produce infected plants is called the seed transmission rate. The lower rate of seed-transmission in PSTVd could be due to the restricted movement of viroids in floral organs. In Nicotiana benthamiana and Solanum lycopersicum, the accumulation of PSTVd was not observed in the petals, ovary and stamens, but detected only in the 
sepals [91]. In petunia, PSTVd is seed-transmitted either through viroid-carrying pollen grains or embryo sacs.

Tomato chlorotic dwarf viroid (TCDVd) of the genus Pospiviroid infects Solanum lycopersicum and is distributed in the ovary and ovules but not in the shoot apical meristem [92,93]. Matsushita et al. [93] reported that TCDVd was found on the surface of the seed coat.

In Capsicum annuum L. PCFVd, another Pospiviroid, was reported to be seed-transmitted [94]. The presence of the Pospiviroids GYSVd 1 and HSVd were found in Vitis vinifera seedlings [95]. ASBVd is an example of Avsunviroid transmitted from infected trees to the seeds of the next generation [96-98]. Another species of family Avsunviroidae genus Pelamoviroid, PLMVd, is not reported to be pollen transmitted and is not seed-transmitted [99-101]. The only known species of genus Elaviroid in the family Avsunviroidae Eggplant latent viroid (ELVd), which is reported to be seed-transmitted via eggplants [102,103].

Additionally, insect-transmitted mechanical inoculation of viroids was demonstrated to be a source of infection through plants via pollen [104]. Insect pests are known for their tendency to transmit PSTVd to Solanum tuberosum (potato) [105]. Myzus persicae, commonly known as green peach, aphid-transmitted PSTVd from other plants coinfected with viruses [106-108]. Apple scar skin viroid (ASSVd) was found to be transmitted by Trialeurodes vaporariorum (whitefly) from viroid-infected plants to cucumber, bean, tomato and pea plants [109].

\section{Pathogenicity of Viroids}

The first complete sequence of the PSTVd was reported by Gross et al. [67]. However, it was assumed that viroid pathogenicity was due to direct interaction with one or more of the host cellular constituents and or by indirect interaction via RNA silencing. Viroid pathogenesis has been shown to be increased due to the interaction with nuclear and cytoplasmic RNAs which results in the activation of protein kinases. It has been reported by Hiddinga et al. [110] that a $68-\mathrm{kDa}$ protein extracted from viroid infected tissues is differentially phosphorylated, and that dsRNA dependent protein kinases similar to their equivalents in mammalian cells are involved in the regulation of viroid synthesis. In this case, the binding of protein kinases enhanced viroid pathogenicity. The PSTVd strains produced different symptoms with only 3-4 nucleotides changed [111] and this change could alter the protein binding site resulting in abnormal function [112]. Infectious cDNA clones were first constructed for PSTVd [113] and then for other viroids to determine their pathogenic determinants [114-116]. It is also noticeable that in some cases, viroid accumulation to high titers is observed although the plants are asymptomatic or while on the contrary, other viroids at low titers cause severe symptoms, which represents the contribution of alternative mechanisms [117].

At the microscopic level, the cytopathogenic effects of viroids on host cellular structures have been reported. For example, for some viroid infections, there is an abnormal development of cytoplasmic membranes to form "plasmalemmasomes", irregular thickening of cell walls [118], chloroplast abnormalities and electron-dense deposits in the cytoplasm and chloroplasts [55].

In recent studies, various molecular mechanisms are involved in the induction of viroid diseases and in this context, RNA silencing has a crucial role in viroid pathogenesis. RNA silencing was first identified in plants and then in other eukaryotes, where it provides other novel regulatory roles in addition to translation. There is very strong evidence that the combined action of the structure-specific dicer-like proteins and the sequence-specific RNA induced silencing complex curb plant RNA and DNA virus infections as well as viroid infections [36,38,119-122]

\section{Viroid-Host Interactions}

Being naked, noncoding RNA molecules, viroids induce disease through direct interaction of their genome with some of the host factors. Despite their simplicity in both genome 
and structure, viroids elicit complex responses in their host plants wherein even with minor changes in their nucleotide sequence, they can induce entirely different symptoms in their host plants based on the cultivar [35]. In general, all viroids elicit "pathogenesis-related" $[P R]$ proteins during their infection cycle [37].

Earlier, the PSTVd was shown to associate with several nuclear and histone proteins of tomato [123]. Initial investigations of the leaf proteins of tomato plants infected with PSTVd revealed a significant increase in the levels of the PR protein, P14 [124]. Introspection into the expression of genes involved in stress response, defense response, chloroplast function and cell wall structure revealed altered expression depending on severity of PSTVd infection $[125,126]$. In another study, the wheat germ RNA polymerase II was shown to interact with terminal loops of the PSTVd [127]. Martínez de Alba et al. [128], demonstrated that the tomato Virp1 bromodomain-containing protein bound to the PSTVd 71-nucleotide bulged TR hairpin structure and that this association played a significant role in systemic spread of the PSTVd [129]. The tomato protein, p68 involved with the ds-RNA-induced protein kinase activity was shown to be differentially phosphorylated by the PSTVd [130,131]. Moreover, the PSTVd was demonstrated to differentially activate the p68 protein based on the severity of the viroid strain, thus implicating the p68 protein in viroid pathogenesis. Interestingly, this differential p68 activation was detected with strains of PSTVd that varied only by a single two-nucleotide inversion within the lower pathogenicity domain of the PSTVd which caused minor variations in their secondary structures. Hammond and Zhao, [132] reported increased transcription of a novel protein kinase (PKV protein) in tomatoes infected by PSTVd depending on the severity of infection. Additionally, they also showed down-regulation of genes responsible for chloroplast biogenesis as well as impacts on the mRNA levels involved in gibberellin biosynthesis and those of some of the signaling hormones. The PSTVd replicates in the nucleus for which the replication start site is present within the hairpin loop of the TL region of its secondary structure and transcription is mediated by the host DNA-dependent RNA polymerase II [133]. In Arabidopsis thaliana, the transcription factor IIIA [TFIIIA] and the ribosomal protein L5 [RPL5] have been shown to play a role in PSTVd replication by binding to the (+) strand of the viroid [134]. Additionally, in Nicotiana benthamiana, the canonical 9-zinc finger [ZF] Transcription Factor IIIA [TFIIIA-9ZF] as well as its variant TFIIIA-7ZF were demonstrated to interact with the PSTVd $(+)$ strand while only the latter recognized the PSTVd (-) strand. Plus, the expression levels of TFIIIA-7ZF directly correlated with viroid replication [135]. PSTVd reportedly recruits the RPL5 splicing regulator to interact with the CCR that plays a critical role in its replication [136,137].

The Cucumis satious Phloem Protein 2 RNA binding protein [CsPP2] was shown to be associated with long distance movement of HSVd RNA by forming a ribonucleoprotein complex $[138,139]$. The CsPP2 was also demonstrated to enhance the efficiency of transfer of the ASSVd through the Trialeurodes vaporariorum [Tv] Whitefly [109]. To-date, the Virp1 and CsPP2 proteins are the best elucidated factors shown to be involved in translocation of the Pospiviroidae. Among Avsunviroidae, the ASBVd infection in avocado revealed the involvement of PARBP33 and PARBP35 chloroplast RNA-binding proteins with the selfcleavage of ASBVd multimer transcripts mediated through hammerhead ribozyme [140].

Tomato plants infected with CEVd showed changes in levels of proteins involved in translation [141]. Additionally, CEVd reportedly induced as well as reduced in vitro phosphorylation of a wide range of proteins when infecting its host plants particularly, at the beginning of symptom appearance [142]. These changes in phosphorylation were enhanced in the presence of $\mathrm{Mn}^{+}{ }^{+}$, demonstrating the significance of $\mathrm{Mn} 2^{+}$-dependent protein kinase action on the varied phosphorylation patterns. In this context, Hidding et al., 1988 [110] reported enhancement in the phosphorylation of a $68 \mathrm{kDa}$ host protein homologous to the human ds-RNA-dependent protein kinase in tomato plants infected with PSTVd. Cottilli et al., 2019 [143] demonstrated changes in the translational machinery of tomato plants infected with the CEVd. They detected the presence of the CEVd within the ribosomal fractions and the CEVd impacted the polysome profiles, specifically causing the 
accumulation of the $40 \mathrm{~S}$ ribosomal subunit. The CEVd was also shown to alter ribosome biogenesis and 18S rRNA maturation. Further, the levels of the ribosomal stress mediator NAC082 was increased in infected leaves. These changes correlated with the extent of disease symptoms caused by CEVd. Therefore, these findings showed that in tomato plants $\mathrm{CEVd}$ causes defective ribosome biogenesis and impacts the machinery of translation resulting in ribosomal stress.

Viroids, even without having any ability to code for proteins, impact the translational machinery. The CEVd has been demonstrated to cause changes in the accretion of ribosomal proteins such as S3, S5 and L10 in tomato plants [141]. It also impacts the levels of the eEF1A, eEF2 and eIF5A eukaryotic translation factors in these plants. Certain viroids have been reported to associate with the eIF1A or with the L5 ribosomal protein $[134,141,144]$. The HSVd elicits alterations in the DNA methylation patterns of the rRNA genes in host plants and results in increased accumulation of some of the rRNA-derived sRNAs [145]. HSVd caused demethylation of some of the rRNA genes leading to transcriptional reactivation of these genes, suggesting a novel molecular mechanism putatively involved in viroid pathogenicity. Moreover, it has been shown that the PSTVd induces degradation of ribosomal protein S3a-like mRNAs in infected tomato plants [146].

Further, an augmented number of differentially regulated genes was observed in peach plants doubly infected with both PLMVd and Prunus necrotic ringspot virus (PNRSV) when compared to those of single infections with either of the two viroids. The double infection also caused a synergistic impact on the peach fruit transcriptome [147]. The PLMVd (that replicates in chloroplasts) upon infection of Prunus persica (peach) induced the expression of six potential RNA-binding polypeptides, one of which is the elongation factor 1-alpha [eEF1A].

\section{Impact of Viroid Infection on Gene Silencing and Indirect Influence of Viroids on Host Genes and miRNAs}

Being noncoding RNAs, viroids do not possess silencing suppressor activities found in viruses [148]. However, several research studies reported the accumulation of 2124 nucleotide-long viroid-derived small RNAs [vd-sRNAs] in viroid-infected plants. Generation of vd-sRNAs impacts disease symptom expression in host plants (Figure 3 [69]). This induction of vd-sRNAs was observed irrespective of the site of viroid replication and showed that viroids can induce RNA silencing of host genes [149-151]. This induction of the vd-sRNA was observed in response to both (+) and (-) strands of the viroid RNA, although the genomic (+) strands induced more vd-sRNA than the antigenomic $(-)$ strands as detected by next-generation sequencing [152-154]. The difference in vd-sRNA accumulation could be due to the lesser levels of accumulation of the $(-)$ strands compared to that of the $(+)$ strands as the former only act as replication intermediates $[73,155,156]$. However, the PSTVd replication was found to be resistant to RNA silencing and could be so by virtue of its inherent secondary structure that renders it recalcitrant to RISCmediated cleavage. The occurrence of vd-sRNA hot spots in viroids reveals the presence of RNA silencing susceptible regions within the secondary structure of the viroids [157]. Deep sequencing of the vd-sRNA from tomato plants [cv. Rutgers] infected with PSTVd showed that most of the vd-sRNAs generated were derived from the PSTVd pathogenicitymodulating domain [49]. PSTVd mutants unable to target host callose synthase mRNAs failed to induce disease symptoms. In PSTVd-infected tomatoes, using algorithms for computer-based target prediction, Adkar-Purushothama and Perreault, 2018 reported a single vd-sRNA capable of promoting RNA silencing of more than one host gene involved in defense mechanisms [158].

Equivalent findings were observed with the Avsunviroid PLMVd [159]. Malfitano et al. [116] reported a PLMVd variant containing a specific 12-13-nt hairpin insertion that causes albinism in susceptible plants. This sequence-dependent induction of disease symptoms is associated with the ability of the PLMVd to targetedly cleave the mRNA that codes for the chloroplast heat-shock protein 90 as evident from deep sequencing, rapid amplification of cDNA ends (RACE) analysis and semi-quantitative reverse transcription-polymerase 
chain reaction (RT-PCR). This implicates the involvement of RNA silencing in symptom expression induced by viroids (Figure 4 [2]). Besides, several other studies showed the role of vd-sRNAs in downregulating host genes [160-162].

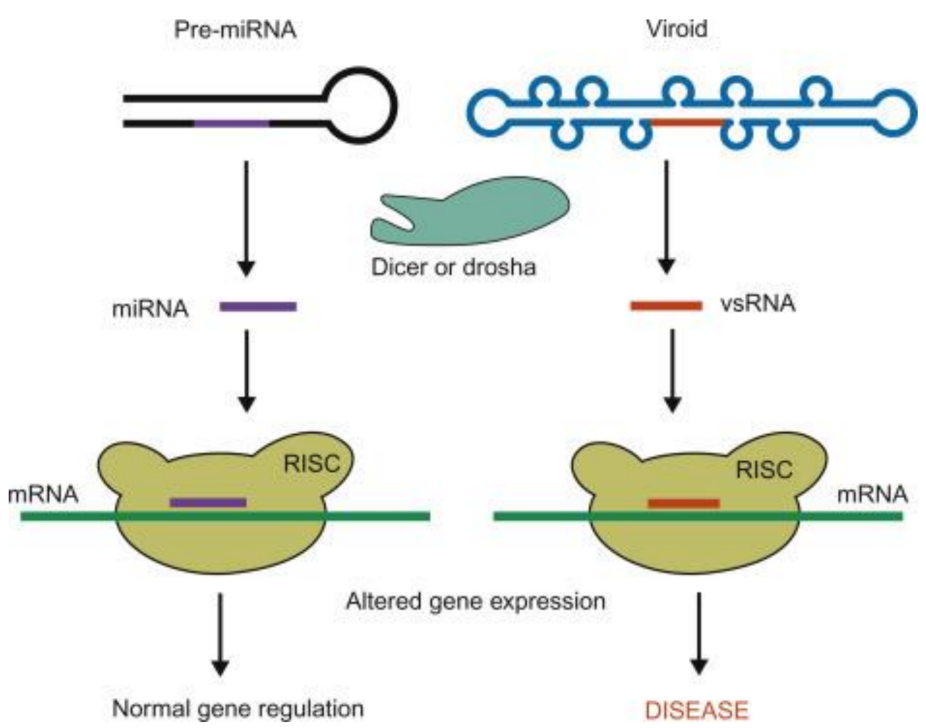

Figure 3. Viroids induce disease by generating viroid small RNA (vsRNA) that elicit RNA interference. (Adapted from Clark et al., 2019 [69]).

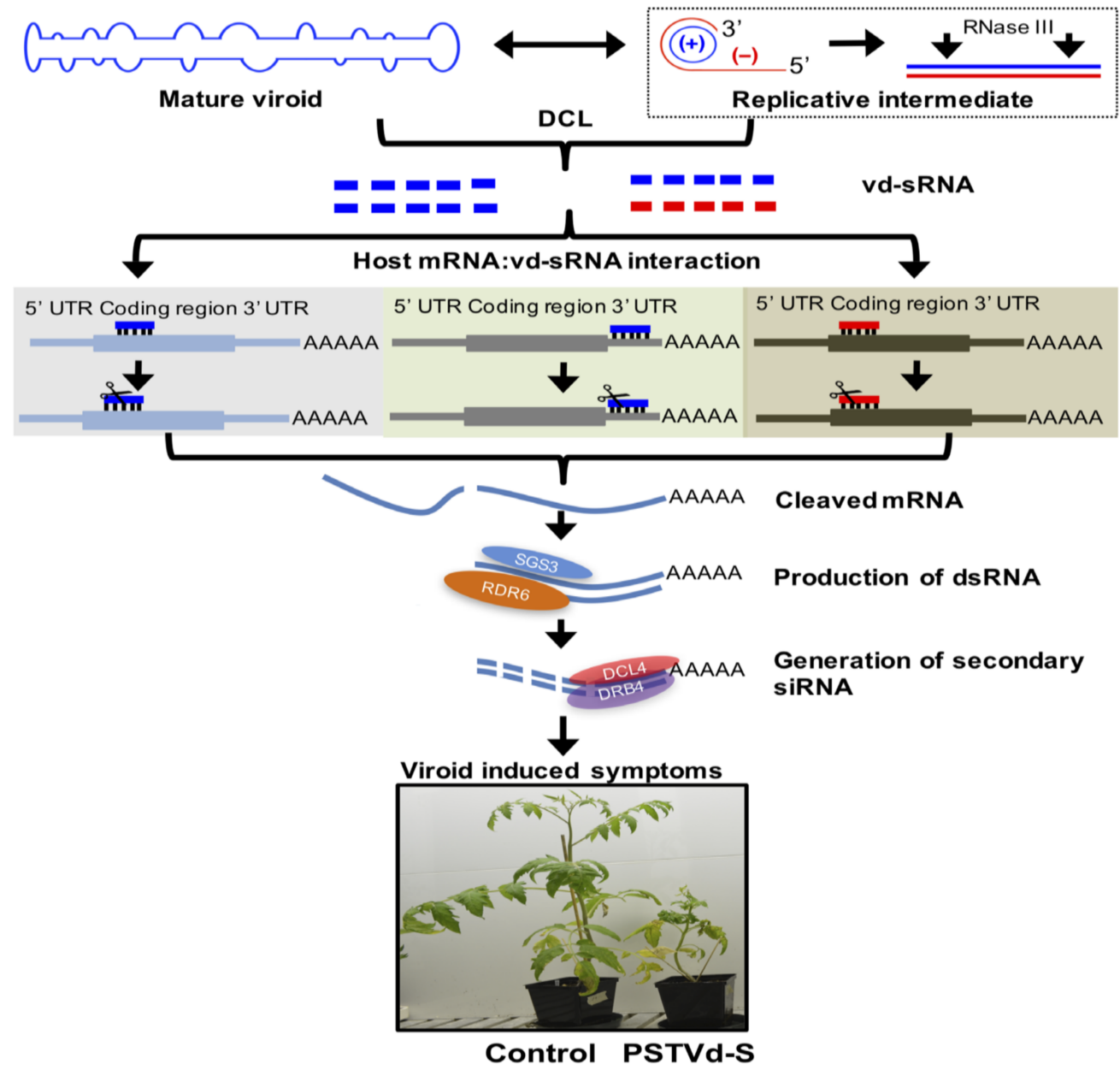

Figure 4. Mechanism of viroid symptom induction. (Adapted from Adkar-Purushotama and Perreault, 2019 [2]). 
PSTVd-infected plants compromised for the host RNA-dependent RNA [RdR] polymerase6 showed enhanced amounts of both vd-sRNAs and PSTVd [163]. In another study, RdR6-silenced line of N. benthamiana plants infected with HSVd showed symptoms in stock plants whereas its scions were bereft of symptoms despite the accumulation of HSVd [164]. Viroid infection induces the generation of secondary siRNAs capable of impacting host mRNAs that are not the direct targets of vd-sRNAs. This phenomenon induced widespread cleavage and destruction of the host plant mRNAs. Earlier studies reported that as part of an antiviroid defense process, the RdR1 polymerase of the host tomato plants was triggered upon PSTVd infection [165]. Additionally, host plant miRNAs involved in leaf development were shown to be accumulated in tomato plants infected with PSTVd. Tsushima et al. [166] used deep sequencing to demonstrate changes in the profile of miRNAs involved in functions such as leaf curling, leaf development and disease resistance in PSTVd-infected tomato plants.

\section{Viroid Detection and Identification}

Viroids can be identified using various techniques. A popular viroid identification method uses biological indexing of a specimen plant on a variety of indicator hosts [21]. The indicator host shows diagnostic symptoms if infected by a particular pathogenic viroid. For better results of biological indexing, a researcher should be able to identify both the host range and the symptoms produced on the host by a specific viroid. Therefore, prior knowledge of the indicator host is necessary before attempting to identify any viroid. Several analytical assays such as RT-PCR, polyacrylamide gel electrophoresis (PAGE) and RT-Loop mediated isothermal AMPlification (RT-LAMP) have been applied for higher-scale sample testing and viroid indexing [21]. Nevertheless, these molecular techniques cannot detect the biological characteristics of the viroids such as their pathogenicity and infectivity. It is therefore evident that biological assays are required to bridge the gap.

There are levels of complexity in viroid identification that depend on knowledge of their molecular properties [21]. The traditional methods of viroid detection involve an assortment of native and denaturing polyacrylamide gel electrophoresis; the method relies on some properties of the viroid RNA such as its circular form to distinguish it from other RNAs. These older methods are still applied to identify the presence of new viroids; however, they cannot be used to identify each specific viroid, since the electrophoretic movement may be common over a wide range.

Viroid detection can also be performed using molecular hybridization. Owens et al. [167] were the first to show how this method can be applied for viroid detection. The technique is useful for detecting viroids from a known sequence; therefore, it relies on the availability of sequence information and is not suitable for the identification of new viroids. On the other hand, RT-PCR can be used for detecting several different viroids and has proven useful in identifying carrier plants that do not show any symptoms. For instance, some researchers used Pospiviroid primers based on a specific sequence to identify several viroids in a natural infection of tomato. A few viroids had not been earlier reported to be found in this crop, and research conducted by Verhoeven et al. [94] demonstrated that this method could be used for detecting new viroids. Additionally, this method is more reliable than those earlier discussed and hence is most used for the detection of viroids. However, the method is extremely sensitive and depends on the knowledge of nucleotide sequence; it is also affected by even a single mutation, which may limit the number of strains detected.

Among the various plant pathogens, viroids are the pathogenic organisms detected for the first-time using RT-PCR [168]. Subsequently, various amplification tools such as real-time RT-PCR [169], RT-PCR- Enzyme-Linked Immuno Sorbent Assay (ELISA) [170], (RT-LAMP) [171], multiplex bead-based array [172], multiplex RT-PCR [173,174] and in situ RT-PCR have been applied for the detection and identification of viroids [175].

End point RT-PCR has been applied for viroid detection in one- [176-178] or two-step reactions [168]. Additionally, polyvalent identification has been employed by multiplex amplification using a mix of specific sets of primers $[173,174,179,180]$. Results for this 
method can be observed through gel electrophoresis or by fluorescent [181] and standard or multiplex RT-PCR-ELISA [170,182]. Boubourakas et al. 2011 [175] adopted a modified RT-PCR technique using SYBR Green for in situ localization and detection of PLMVd.

Real-time RT-PCR has been used for viroid detection, assessment of plant resistance, viroid transmission and genotyping [169,183-188]. Additionally, qRT-PCR helps in quantitating the amounts of the concerned viroids.

Notomi et al. 2000 [189] first formulated the Loop-mediated isothermal AMPlification (LAMP) technique in which at least four primers specifically capable of recognizing six distinct nucleotide sequences on the target template under isothermal conditions $\left(60-65{ }^{\circ} \mathrm{C}\right)[189,190]$ were used. Prior to the LAMP amplification procedure, RT reaction was carried out separately $[191,192]$ or along with the LAMP reaction $[193,194]$ using reverse transcriptase enzymes that can withstand $60-65^{\circ} \mathrm{C}$ reaction temperature. The LAMP technique is based on the DNA strand-displacement activity of the Bst DNA polymerase and the reaction components include dNTPs in high amounts, magnesium sulfate and betaine used to diminish base stacking and to enhance target sequence selectivity [195]. The end products of LAMP are obtained as DNAs that are double-stranded stem-loops containing many inverted repeats of the target sequence as well as multiple loops forming cauliflower-like structures $[189,190]$. Therefore, the RT-LAMP reaction generates high DNA yield and the increased quantity of the produced by-product magnesium pyrophosphate enables direct visualization as a white-colored precipitate in positive samples [194] Additionally, end point measurements or real-time turbidity assessments can be assayed at $400 \mathrm{~nm}[192,193]$. Upon gel electrophoresis, the RT-LAMP reaction products appear ladder-like because of the cauliflower-like structures [196]. Thus, RT-LAMP technique by virtue of its simplicity, ease of use and power of detection helps in translating research in the laboratory to the field level. Table 3 lists some of the viroids for which RT-LAMP procedures have been adopted.

Table 3. Viroid species for which RT-LAMP protocols were developed. (Adapted from Panno et al. 2020 [197]).

\begin{tabular}{ccccc}
\hline Species & Acronym & Family & Genus & Reference \\
\hline $\begin{array}{c}\text { Apple scar skin viroid } \\
\begin{array}{c}\text { Chrysanthemum chlorotic } \\
\text { mottle viroid }\end{array}\end{array}$ & ASSVd & Pospiviroidae & Apscaviroid & {$[198]$} \\
\hline $\begin{array}{c}\text { Chrysanthemum stunt viroid } \\
\text { Coconut cadang-cadang viroid }\end{array}$ & CSVd & Pospiviroidae & Pospiviroid & {$[199]$} \\
\hline Columnea latent viroid & CLVd & Pospiviroidae & Pospiviroid & {$[200]$} \\
\hline Peach latent mosaic viroid & PLMVd & Avsunviroidae & Pelamoviroid & {$[193]$} \\
\hline Pepper chat fruit viroid & PCFVd & Pospiviroidae & Pospiviroid & {$[201]$} \\
\hline Potato spindle tuber viroid & PSTVd & Pospiviroidae & Pospiviroid & {$[194]$} \\
\hline
\end{tabular}

Microarrays serve as an optimal platform for one-step diagnosis of multiple viroid infections [30]. The numerous viroid nucleotide sequences obtained from public databases can be used to generate microarrays that enable detection of all of these viroids simultaneously. Additionally, related viroids can be identified by their unique hybridization patterns. Further, microarrays can be used for discovering new viroids by incorporating microarray elements derived from highly conserved sequences of viroid families, genera or species, particularly in cases involving plant diseases of unknown etiology.

The advantage of microarrays lies in their ability to detect a wide range of viroids using just a single test in addition to enabling highly specific oligonucleotide-based identification and ease of in silico design. Thus, mixed infections due to various viroids as well as related strains can be identified. However, the main caveat of this method is its complex and expensive detection process. Microarrays have been used in the identification of 
Pospiviroidae such as Tomato apical stunt viroid (TASVd) in tomato [202,203], PSTVd in potato [203,204], ASSVd in apples [203] and Citrus dwarfing viroid (CDVd) in citrus [203] as well as Avsunviroidae such as ASBVd in avocado [203], CChMVd in chrysanthemum [203] and PLMVd in peach [203].

NGS biotechnologies and bioinformatics were initially used for the detection and analysis of viroids in 2009 [205]. NGS can provide sequence information on the multitudes of the viroid-derived sRNAs in infected plant materials. Thus, depending on the abundance of vd-sRNAs the molecular fragments of the viroid can be assembled. Due to the small size of the vd-sRNAs (21-24 nucleotides), their sequences can be directly used as primer sequences in RT-PCR amplification of viroid fragments. Detection of plant infections of unknown etiology could be attributed to viroids among other plant pathogens. Two new viroids, the persimmon viroid 2 [206] and GLVd [32] were discovered using NGS. Additionally, the infections of fig and hops trees with the apple dimple fruit viroid (ADFVd) [207] and CBCVd [208], respectively, were discovered using NGS and this showed their wide host range. Table 4 lists some of the viroids and their variants detected by NGS techniques.

Table 4. Examples of novel viroids and variants discovered by next-generation sequencing (NGS) technologies. (Adapted from Hadidi, 2019) [12].

\begin{tabular}{ccc}
\hline Viroid & Description & Reference Source \\
\hline Persimmon viroid-2 & A novel apscaviroid & Ito et al. 2013 [206] \\
\hline Grapevine latent viroid & A novel apscaviroid & Zhang et al. 2014 [32] \\
\hline Apple dimple fruit viroid & $\begin{array}{c}\text { A novel variant that naturally } \\
\text { infects fig }\end{array}$ & Chiumenti et al. 2014 [207] \\
& A novel variant that naturally & infects hops \\
CBCVd & $\begin{array}{c}\text { Two novel citrus variants } \\
\text { closely related to hop variants }\end{array}$ & $\begin{array}{c}\text { Jakse et al. 2015 [208] } \\
\text { Wang et al. 2018 [209] }\end{array}$ \\
\hline
\end{tabular}

Importantly, NGS has become a powerful tool for viroid detection and amplification without prior knowledge of the viroid nucleotide sequence. NGS affords a quick, accurate and sensitive detection technique for identifying viroids affecting several host species and even detecting infections of woody perennials having low titers of these pathogenic organisms. Thus, the detection of newer viroids and their variants has become possible while helping to extend the host range of these viroids. NGS-based diagnosis of viroids has become important for quarantine and certification schemes in addition to operations aimed at elimination of viroid contamination from vegetatively propagated plant material [210-213]. This makes NGS an efficiently powerful tool to control and contain viroid diseases. If the NGS technology were used in combination with genome engineering methods such as the CRISPR/cas9 system, this will enable better control of these viroids [214-216].

Plant pathology necessitates the practice of Koch's postulates wherein a given RNA molecule with the physicochemical characteristics of a viroid can be cloned and properly assessed in terms of its ability to cause infection upon inoculation and thus determine its biological activity. Therefore, bioassays will invariably have a pivotal role in viroid research. It is obvious that the biological and molecular assays when used synergistically can provide an efficient means for detection, identification and characterization of viroids.

\section{Origin and Evolution of Viroids}

Viroid evolutionary history was proposed to have started independently and earlier than the evolution of DNA and protein in the original RNA world [217]. It is a unique example to study the complex processes of evolution in an extremely simple biological system where expression of phenotype depends directly on the genotype [218]. Infectious agents such as RNA viruses are considered to be directly related to viroids and it has been hypothesized that viroids are the primitive form of RNA viruses [219]. However, there 
is an alternative hypothesis which suggests that viroids originated from either nuclear RNAs [219], introns [220,221], transposable elements [222] or mitochondrial retroplasmids, which were dismissed based on investigative evidence. Therefore, as suggested by Diener [223], viroids are better candidates to be considered as "living fossils" of a pre-cellular RNA world than introns.

Viroids are subject to strong selection pressure to maintain the internal base pairing of their secondary structure in order to avoid host defense cellular degradation by RNA silencing or plant nucleases. The secondary structure of the viroid RNA is a classic example of an optimal compromise between the essential need for survival against the host defense mechanism and the requirement to recruit host cellular network for replication and transfer $[14,224]$.

Wassenegger and his team [225] demonstrated that a single nucleotide change within the viroid genome can affect its ability to infect the host. This generates a closely resembling sequence variants of viroids exhibiting different host invading properties. On the other hand, some of the plants become host to a number of viroids of distinct genera and even get infected with a mixture of viroids and viruses, which facilitates the swift evolution of viroids [19]. Experiments of site-directed mutagenesis resulted into different disease outcomes indicating that when viroids are exposed to selective pressures, extremely rapid evolution is observed. Under stressful environments for one viroid species, another more suitable and fit quasispecies with variant nucleotide sequence becomes dominant within a very short time period. This extreme capability of genome plasticity distinguishes viroids as the most promptly evolving biological system.

\section{Future Perspective and Research}

Earlier research was directed towards understanding the roles of the structural/functional motifs within the viroid responsible for the induction of viroid-associated symptoms. Then, attention turned towards investigating viroid-host protein interactions. More recently, viroid research has focused on the analysis of the transcriptome of viroid-infected host plants using RNA-seq and other next-generation sequencing technologies and bioinformatics analyses [226]. The viroid-derived small RNA (vd-sRNA) discovered in plants infected with viroids [150] and its role in subverting host gene expression through RNA silencing have implicated the involvement of the vd-sRNA in the expression of viroid-induced disease symptoms. This vd-sRNA-mediated sequence-specific modulation of host gene expression could explain why even a minor sequence change between viroid strains could elicit a wide array of symptoms in susceptible plant cultivars. This calls for further research to explain the molecular mechanism(s) behind the extensive genome degradation seen in the viroid-infected host plants.

Viroids have also been implicated in affecting the host translational machinery. Investigation of the polysome fractions of tomato plants infected with CEVd or PSTVd have identified the presence of the viroid molecule within the ribosomal fraction which show the involvement of viroids in inducing ribosomal stress by direct intervention of the plant translational machinery [143]. However, which viroid regions are involved in such translational interference is yet to be identified. Advancements such as deep sequencing of the extracted polysomes in viroid-infected plants are called for. This could shed further light into our knowledge of viroid-host interactions and their role in determining viroid pathogenicity.

In vitro molecular modeling using thermodynamic folding-based structure predictions as well as direct visualization of the viroid genome by atomic force microscopy are increasingly employed to identify the most stable viroid structure occurring within the cell [227]. This will shed light into the how the mature viroids escape the RNA silencing machinery of their hosts despite triggering the silencing of the host genes. Evidently, the past five decades of viroid research have led to better discernment of viroid structure, molecular biology, pathogenicity and viroid-host interactions. The recent interest in research on coding and noncoding circular RNAs in mammalian cells [228] and their respective functions has resulted in implicating the roles of circular RNAs in diseases such 
as cancer in humans. Further introspection into the molecular nature and impact of viroids could reveal valuable insights into the nature of circular RNAs in systems other than plants. Thus, viroids despite being minuscule and simple in terms of genomic composition and structure are far more complex than was originally envisioned.

\section{Conclusions}

The literature described above demonstrates that viroid research is flourishing and has uncovered novel methods to characterize various population structures of viroids and how they undergo replication, movement, plant-to-plant transmission and perform host-specific interactions. Considering the appearance of new and recombinant viroids, there is a compelling need to evolve more efficient detection and identification techniques on a continual basis. This will definitely help in the discovery of new intervention techniques to preclude viroid replication and movement and ultimately quell/control viroid-induced diseases.

Author Contributions: S.V., U.B., E.S. and G.H. contributed equally to this manuscript. K.H. was responsible for conceptualization, review and editing. M.A. reviewed the manuscript. All authors have read and agreed to the published version of the manuscript.

Funding: This research received no external funding.

Institutional Review Board Statement: Not applicable.

Informed Consent Statement: Not applicable.

Data Availability Statement: Not applicable.

Conflicts of Interest: The authors declare there are no conflict of interest.

\section{References}

1. Adkar-Purushothama, C.R.; Perreault, J.-P. Suppression of RNA-Dependent RNA polymerase 6 favors the accumulation of potato spindle tuber viroid in Nicotiana Benthamiana. Viruses 2019, 11, 345. [CrossRef]

2. Adkar-Purushothama, C.R.; Perreault, J.-P. Current overview on viroid-host interactions. Wiley Interdiscip. Rev. RNA 2020, 11, e1570. [CrossRef]

3. Diener, T.; Raymer, W.B. Potato Spindle Tuber Virus: A Plant Virus with Properties of a Free Nucleic Acid. Science 1967, 158, 378-381. [CrossRef]

4. Diener, T.O. Potato spindle tuber "virus": IV. A replicating, low molecular weight RNA. Virology 1971, 45, 411-428.

5. Diener, T.O. Of Viroids and Prions. Viruses 2018, 10, 663. [CrossRef]

6. Diener, T.O. Discovering viroids-A personal perspective. Nat. Rev. Microbiol. 2003, 1, 75-80.

7. Sänger, H.L. An infectious and replicating RNA of low molecular weight: The Agent of the Exocortis disease of citrus. In Proceedings of the Workshop on Mechanisms and Prospects of Genetic Exchange, Berlin, Germany, 11-13 December 1971; pp. 103-116.

8. Semancik, J.; Weathers, L. Exocortis virus: An infectious free-nucleic acid plant virus with unusual properties. Virology 1972, 47, 456-466. [CrossRef]

9. Diener, T.; Lawson, R. Chrysanthemum stunt: A viroid disease. Virology 1973, 51, 94-101. [CrossRef]

10. Hollings, M.; Stone, O.M. Some properties of chrysanthemum stunt, a virus with the characteristics of an uncoated ribonucleic acid. Ann. Appl. Biol. 1973, 74, 333-348. [CrossRef]

11. Di Serio, F.; Li, S.-F.; Pallas, V.; Owens, R.A.; Randles, J.W.; Sano, T.; Verhoeven, T.J.; Vidalakis, G.; Flores, R. Viroid taxonomy. In Viroids and Satellites; Hadidi, A., Flores, R., Randles, J.W., Palukaitis, P., Eds.; Academic Press: Oxford, UK, 2017 ; pp. 134-146. ISBN 978-0-12-801498-1.

12. Hadidi, A. Next-generation sequencing and CRISPR/Cas13 editing in viroid research and molecular diagnostics. Viruses 2019, 11, 120. [CrossRef]

13. Choi, H.; Jo, Y.; Cho, W.K.; Yu, J.; Tran, P.T.; Salaipeth, L.; Kwak, H.; Choi, H.; Kim, K. Identification of viruses and viroids infecting tomato and pepper plants in vietnam by metatranscriptomics. Int. J. Mol. Sci. 2020, 21, 7565.

14. Ding, B. The biology of viroid-host interactions. Annu. Rev. Phytopathol. 2009, 47, 105-131. [CrossRef]

15. Flores, R.; Hernández, C.; De Alba, A.E.M.; Daròs, J.-A.; Di Serio, F. Viroids and viroid-host interactions. Annu. Rev. Phytopathol. 2005, 43, 117-139. [CrossRef]

16. Fraenkel-Conrat, H.; Williams, R.C. Reconstitution of active tobacco mosaic virus from its inactive protein and nucleic acid components. Proc. Natl. Acad. Sci. USA 1955, 41, 690-698. [CrossRef]

17. Di Serio, F.; Flores, R.; Verhoeven, J.T.J.; Li, S.-F.; Pallás, V.; Randles, J.W.; Sano, T.; Vidalakis, G.; Owens, R.A. Current status of viroid taxonomy. Arch. Virol. 2014, 159, 3467-3478. [CrossRef] 
18. Prol, F.V.; López-Gresa, M.P.; Rodrigo, I.; Bellés, J.M.; Lisón, P. Ethylene is involved in symptom development and ribosomal stress of tomato plants upon citrus exocortis viroid infection. Plants 2020, 9, 582.

19. Więsyk, A.; Lirski, M.; Fogtman, A.; Zagórski-Ostoja, W.; Góra-Sochacka, A. Differences in gene expression profiles at the early stage of Solanum lycopersicum infection with mild and severe variants of potato spindle tuber viroid. Virus Res. 2020, 286, 198090. [CrossRef]

20. Flores, R.; Minoia, S.; Carbonell, A.; Gisel, A.; Delgado, S.; López-Carrasco, A.; Navarro, B.; Di Serio, F. Viroids, the simplest RNA replicons: How they manipulate their hosts for being propagated and how their hosts react for containing the infection. Virus Res. 2015, 209, 136-145. [CrossRef]

21. Hadidi, A.; Flores, R.; Randles, J.W.; Palukaitis, P. Viroids and Satellites; Academic Press: Cambridge, MA, USA; Elsevier: Oxford, UK, 2017; ISBN 978-0-12-801498-1.

22. Kovalskaya, N.; Hammond, R.W. Molecular biology of viroid-host interactions and disease control strategies. Plant Sci. 2014, 228, 48-60. [CrossRef]

23. Wang, Y.; Ding, B. Viroids: Small Probes for Exploring the Vast Universe of RNA Trafficking in Plants. J. Integr. Plant Biol. 2010, 52, 28-39. [CrossRef]

24. Ding, B.; Itaya, A. Viroid: A useful model for studying the basic principles of infection and RNA biology. Mol. Plant Microbe Interact. 2007, 20, 7-20. [CrossRef]

25. Heinlein, M. Plant virus replication and movement. Virology 2015, 479-480, 657-671. [CrossRef]

26. Qi, Y.; Pélissier, T.; Itaya, A.; Hunt, E.; Wassenegger, M.; Ding, B. Direct role of a viroid RNA motif in mediating directional RNA trafficking across a specific cellular boundary. Plant Cell 2004, 16, 1741-1752. [CrossRef]

27. Tabler, M.; Tsagris, M. Viroids: Petite RNA pathogens with distinguished talents. Trends Plant Sci. 2004, 9, 339-348. [CrossRef]

28. Taliansky, M.; Torrance, L.; Kalinina, N.O. Role of plant virus movement proteins. In Plant Virology Protocols: Methods in Molecular Biology ${ }^{\mathrm{TM}}$; Foster, G.D., Johansen, I.E., Hong, Y., Nagy, P.D., Eds.; Humana Press: Totowa, NJ, USA, 2008; Volume 451, pp. 33-54. [CrossRef]

29. Waterworth, H.; Hadidi, A. Economic losses due to plant viruses. In Plant Virus Disease Control; Hadidi, A., Khetarpal, R.K., Koganezawa, H., Eds.; APS Press: St. Paul, MN, USA, 1998; pp. 1-13. ISBN 0-89054-191-4.

30. Zhu, S.; Zhang, Y.; Tiberini, A.; Barba, M. Detection and identification of viroids by microarrays. In Viroids and Satellites; Hadidi, A., Flores, R., Randles, J.W., Palukaitis, P., Eds.; Academic Press: Cambridge, MA, USA; Elsevier: Oxford, UK, 2017; Chapter 37; ISBN 978-0-12-801498-1.

31. Wu, Q.; Wang, Y.; Cao, M.; Pantaleo, V.; Burgyan, J.; Li, W.-X.; Ding, S.-W. Homology-independent discovery of replicating pathogenic circular RNAs by deep sequencing and a new computational algorithm. Proc. Natl. Acad. Sci. USA 2012, 109, $3938-3943$.

32. Zhang, Z.; Qi, S.; Tang, N.; Zhang, X.; Chen, S.; Zhu, P.; Ma, L.; Cheng, J.; Xu, Y.; Lu, M.; et al. Discovery of Replicating Circular RNAs by RNA-Seq and Computational Algorithms. PLoS Pathog. 2014, 10, e1004553. [CrossRef]

33. Adkar-Purushothama, C.R.; Kanchepalli, P.R.; Yanjarappa, S.M.; Zhang, Z.; Sano, T. Detection, distribution, and genetic diversity of Australian grapevine viroid in grapevines in India. Virus Genes 2014, 49, 304-311. [CrossRef]

34. Sahana, A.B.; Adkar-Purushothama, C.R.; Chennappa, G.; Zhang, Z.X.; Sreenivasa, M.Y.; Sano, T. First Report of Grapevine yellow speckle viroid-1 and Hop stunt viroid Infecting Grapevines (Vitis vinifera) in India. Plant Dis. 2013, 97, 1517. [CrossRef]

35. Mishra, A.K.; Kumar, A.; Mishra, D.; Nath, V.S.; Jakše, J.; Kocábek, T.; Killi, U.K.; Morina, F.; Matoušek, J. Genome-wide transcriptomic analysis reveals insights into the response to citrus bark cracking viroid (CBCVd) in hop (Humulus lupulus L.). Viruses 2018, 10, 570. [CrossRef]

36. Xia, C.; Li, S.; Hou, W.; Fan, Z.; Xiao, H.; Lu, M.; Sano, T.; Zhang, Z. Global transcriptomic changes induced by infection of cucumber (Cucumis satioum L.) with mild and severe variants of hop stunt viroid. Front. Microbiol. 2017, 8, 2427.

37. Štajner, N.; Radišek, S.; Mishra, A.K.; Nath, V.S.; Matoušek, J.; Jakše, J. Evaluation of Disease Severity and Global Transcriptome Response Induced by Citrus bark cracking viroid, Hop latent viroid, and Their Co-Infection in Hop (Humulus lupulus L.). Int. J. Mol. Sci. 2019, 20, 3154. [CrossRef]

38. Zheng, Y.; Wang, Y.; Ding, B.; Fei, Z. Comprehensive transcriptome analyses reveal that potato spindle tuber viroid triggers genome-wide changes in alternative splicing, inducible trans-acting activity of phased secondary small interfering RNAs, and immune responses. J. Virol. 2017, 91, e00247-17. [CrossRef]

39. Gago-Zachert, S. Viroids, infectious long non-coding RNAs with autonomous replication. Virus Res. 2016, 212, 12-24. [CrossRef]

40. Steger, G.; Riesner, D. Viroid research and its significance for RNA technology and basic biochemistry. Nucleic Acids Res. 2018, 46, 10563-10576. [CrossRef]

41. Tsagris, E.M.; Martínez de Alba, A.E.; Gozmanova, M.; Kalantidis, K. Viroids. Cell. Microbiol. 2008, 10, $2168-2179$.

42. Diener, T.O. Viroids: "Living fossils" of primordial RNAs? Biol. Direct 2016, 11, 15. [CrossRef]

43. Singh, R.P.; Ready, K.F.M.; Nie, X. Biology; CSIRO Publishing: Collingwood, VIC, Australia, 2003.

44. Góra-Sochacka, A. Viroids: Unusual small pathogenic RNAs. Acta Biochim. Pol. 2004, 51, 587-607. [CrossRef]

45. Takeda, R.; Ding, B. Viroid intercellular trafficking: RNA motifs, cellular factors and broad impacts. Viruses 2009, 1, 210-221. [CrossRef]

46. Dalakouras, A.; Dadami, E.; Wassenegger, M. Viroid-induced DNA methylation in plants. Biomol. Concepts 2013,4 , 557-565. [CrossRef] 
47. Dalakouras, A.; Dadami, E.; Wassenegger, M.; Krczal, G.; Wassenegger, M. RNA-directed DNA methylation efficiency depends on trigger and target sequence identity. Plant J. 2016, 87, 202-214. [CrossRef]

48. Matousek, J.; Kozlová, P.; Orctová, L.; Schmitz, A.; Pesina, K.; Bannach, O.; Diermann, N.; Steger, G.; Riesner, D. Accumulation of viroid-specific small RNAs and increase in nucleolytic activities linked to viroid-caused pathogenesis. Biol. Chem. 2007, 388, 1-13.

49. Diermann, N.; Matoušek, J.; Junge, M.; Riesner, D.; Steger, G. Characterization of plant miRNAs and small RNAs derived from potato spindle tuber viroid (PSTVd) in infected tomato. Biol. Chem. 2010, 391, 1379-1390. [CrossRef]

50. Adkar-Purushothama, C.R.; Brosseau, C.; Giguère, T.; Sano, T.; Moffett, P.; Perreault, J.-P. Small RNA derived from the virulence modulating region of the potato spindle tuber viroid silences callose synthase genes of tomato plants. Plant Cell 2015, 27, 2178-2194. [CrossRef]

51. Flores, R.; De La Peña, M.; Navarro, J.-A.; Ambrós, S.; Navarro, B. Molecular biology of viroids. In Molecular Biology of Plant Viruses; Mandahar, C.L., Ed.; Springer: Boston, MA, USA, 1999; pp. 225-239.

52. Bull, J.J.; Meyers, L.A.; Lachmann, M. Quasispecies Made Simple. PLoS Comput. Biol. 2005, 1, e61. [CrossRef]

53. Serra, P.; Hashemian, S.M.B.; Fagoaga, C.; Romero, J.; Ruiz-Ruiz, S.; Gorris, M.T.; Bertolini, E.; Duran-Vila, N. Virus-viroid interactions: Citrus tristeza virus enhances the accumulation of citrus dwarfing viroid in mexican lime via virus-encoded silencing suppressors. J. Virol. 2013, 88, 1394-1397. [CrossRef]

54. Rodio, M.-E.; Delgado, S.; De Stradis, A.; Gómez, M.-D.; Flores, R.; Di Serio, F. A viroid RNA with a specific structural motif inhibits chloroplast development. Plant Cell 2007, 19, 3610-3626.

55. Di Serio, F.; De Stradis, A.; Delgado, S.; Flores, R.; Navarro, B. Cytopathic effects incited by viroid RNAs and putative underlying mechanisms. Front. Plant Sci. 2013, 3, 288. [CrossRef]

56. Di Serio, F.; Li, S.-F.; Matoušek, J.; Owens, R.A.; Pallás, V.; Randles, J.W.; Sano, T.; Verhoeven, J.T.J.; Vidalakis, G.; Flores, R.; et al. ICTV virus taxonomy profile: Avsunviroidae. J. Gen. Virol. 2018, 99, 611-612. [CrossRef]

57. Faggioli, F.; Luigi, M.; Sveikauskas, V.; Olivier, T.; Marn, M.V.; Plesko, I.M.; De Jonghe, K.; Van Bogaert, N.; Grausgruber-Gröger, S. An assessment of the transmission rate of four pospiviroid species through tomato seeds. Eur. J. Plant Pathol. 2015, 143, 613-617. [CrossRef]

58. Matsushita, Y.; Yanagisawa, H.; Sano, T. Vertical and horizontal transmission of pospiviroids. Viruses 2018, 10, 706. [CrossRef]

59. Matoušek, J.; Steinbachová, L.; Drábková, L.Z.; Kocábek, T.; Potěšil, D.; Mishra, A.K.; Honys, D.; Steger, G. Elimination of viroids from tobacco pollen involves a decrease in propagation rate and an increase of the degradation processes. Int. J. Mol. Sci. 2020, 21, 3029. [CrossRef]

60. Nath, V.S.; Shrestha, A.; Awasthi, P.; Mishra, A.K.; Kocábek, T.; Matoušek, J.; Sečnik, A.; Jakše, J.; Radišek, S.; Hallan, V. Mapping the gene expression spectrum of mediator subunits in response to viroid infection in plants. Int. J. Mol. Sci. 2020, $21,2498$. [CrossRef]

61. King, A.M.Q.; Lefkowitz, E.; Adams, M.J.; Carstens, E.B. Virus Taxonomy: Ninth Report of the International Committee on Taxonomy of Viruses; Elsevier: Amsterdam, The Netherlands, 2011; Volume 9.

62. Rocheleau, L.; Pelchat, M. The subviral RNA database: A toolbox for viroids, the hepatitis delta virus and satellite RNAs research. BMC Microbiol. 2006, 6, 24.

63. Ding, B.; Zhong, X. Viroids/Virusoids. In Microbiology, 3rd ed.; Elsevier: Amsterdam, The Netherlands, 2009 ; pp. 535-545.

64. Matsushita, Y.; Tsuda, S. Host ranges of Potato spindle tuber viroid, Tomato chlorotic dwarf viroid, Tomato apical stunt viroid, and Columnea latent viroid in horticultural plants. Eur. J. Plant Pathol. 2014, 141, 193-197. [CrossRef]

65. Flores, R.; Di Serio, F.; Hernández, C. Viroids: The noncoding genomes. Semin. Virol. 1997, 8, 65-73. [CrossRef]

66. Adkar-Purushotama, C.R.; Perreault, J.P. Impact of nucleic acid sequencing on viroid biology. Int. J. Mol. Sci. 2020, $21,5532$.

67. Gross, H.J.; Domdey, H.; Lossow, C.; Jank, P.; Raba, M.; Alberty, H.; Singer, H.L. Nucleotide sequence and secondary structure of potato spindle tuber viroid. Nature 1978, 273, 203-208.

68. Daròs, J.; Elena, S.F.; Flores, R. Viroids: An Ariadne's thread into the RNA labyrinth. EMBO Rep. 2006, 7, 593-598. [CrossRef]

69. Clark, D.P.; Pazdernik, N.J.; McGehee, M.R. Chapter 24-viruses, viroids, and prions. In Molecular Biology, 3rd ed.; Clark, D.P., Pazdernik, N.J., McGehee, M.R., Eds.; Academic Cell; Elsevier: Amsterdam, The Netherlands, 2019; pp. 749-792.

70. Branch, A.D.; Benenfeld, B.J.; Robertson, H.D. Evidence for a single rolling circle in the replication of potato spindle tuber viroid. Proc. Natl. Acad. Sci. USA 1988, 85, 9128-9132.

71. Feldstein, P.A.; Hu, Y.; Owens, R.A. Precisely full length, circularizable, complementary RNA: An infectious form of potato spindle tuber viroid. Proc. Natl. Acad. Sci. USA 1998, 95, 6560-6565. [CrossRef]

72. Flores, R.; Daròs, J.A.; Hernandez, C. The Avsunviroidae family: Viroids with hammerhead ribozymes. Adv. Virus Res. 2000, 55, 271-323.

73. Hutchins, C.J.; Rathjen, P.D.; Forster, A.C.; Symons, R.H. Self-cleavage of plus and minus RNA transcripts of avocado sunblotch viroid. Nucleic Acids Res. 1986, 14, 3627-3640. [CrossRef]

74. Navarro, J.A.; Daròs, J.A.; Flores, R. Complexes containing both polarity strands of avocado sunblotch viroid: Identification in chloroplasts and characterization. Virology 1999, 253, 77-85.

75. Daròs, J.A.; Marcos, J.F.; Hernandez, C.; Flores, R. Replication of avocado sunblotch viroid: Evidence for a symmetric pathway with two rolling circles and hammerhead ribozyme processing. Proc. Natl. Acad. Sci. USA 1994, 91, 12813-12817.

76. Flores, R.; Minoia, S.; López-Carrasco, A.; Delgado, S.; De Alba, A.E.M.; Kalantidis, K. Viroid replication. In Viroids and Satellites; Academic Press: Oxford, UK, 2017; pp. 71-81. 
77. Diener, T.O. Viroids and the Nature of Viroid Diseases; Springer: Vienna, Austria, 1999; Volume 15.

78. Zhong, X.; Archual, A.J.; Amin, A.A.; Ding, B. A Genomic map of viroid RNA motifs critical for replication and systemic trafficking. Plant Cell 2008, 20, 35-47. [CrossRef]

79. Steger, G.; Perreault, J.-P. Structure and associated biological functions of viroids. Adv. Virus Res. 2016, 94, 141-172. [CrossRef]

80. Zhong, X.; Tao, X.; Stombaugh, J.; Leontis, N.B.; Ding, B. Tertiary structure and function of an RNA motif required for plant vascular entry to initiate systemic trafficking. EMBO J. 2007, 26, 3836-3846. [CrossRef]

81. Jiang, D.; Wang, M.; Li, S. Functional analysis of a viroid RNA motif mediating cell-to-cell movement in Nicotiana benthamiana J. Gen. Virol. 2017, 98, 121-125. [CrossRef]

82. Takeda, R.; Petrov, A.I.; Leontis, N.B.; Ding, B. A Three-Dimensional RNA Motif in Potato spindle tuber viroid Mediates Trafficking from Palisade Mesophyll to Spongy Mesophyll in Nicotiana benthamiana. Plant Cell 2011, 23, 258-272. [CrossRef]

83. Ding, B.; Kwon, M.-O.; Hammond, R.; Owens, R. Cell-to-cell movement of potato spindle tuber viroid. Plant J. 1997, 12, 931-936. [CrossRef]

84. Palukaitis, P. Potato spindle tuber viroid: Investigation of the long-distance, intra-plant transport route. Virology 1987, 158, 239-241. [CrossRef]

85. Mink, G.I. Pollen and seed-transmitted viruses and viroids. Annu. Rev. Phytopathol. 1993, 31, 375-402.

86. Johansen, E.; Edwards, M.C.; Hampton, R.O. Seed transmission of viruses: Current perspectives. Annu. Rev. Phytopathol. 1994, 32, 363-386.

87. Hull, R. Transmission 2: Mechanical, Seed, Pollen and Epidemiology; Elsevier Academic Press: Amsterdam, The Netherlands, 2004.

88. Card, S.D.; Pearson, M.N.; Clover, G.R.G. Plant pathogens transmitted by pollen. Australas. Plant Pathol. 2007, 36, 455-461. [CrossRef]

89. Constable, F.E.; Chambers, G.; Penrose, L.; Daly, A.; Mackie, J.; Davis, K.; Rodoni, B.; Gibbs, M. Viroid-infected tomato and capsicum seed shipments to Australia. Viruses 2019, 11, 98. [CrossRef]

90. Zhu, Y.; Qi, Y.; Xun, Y.; Owens, R.; Ding, B. Movement of potato spindle tuber viroid reveals regulatory points of phloem-mediated RNA Traffic. Plant Physiol. 2002, 130, 138-146. [CrossRef]

91. Matsushita, Y.; Tsuda, S. Distribution of potato spindle tuber viroid in reproductive organs of petunia during its developmental stages. Phytopathology 2014, 104, 964-969. [CrossRef]

92. Singh, R.P.; Dilworth, A.D. Tomato chlorotic dwarf viroid in the ornamental plant Vinca minor and its transmission through tomato seed. Eur. J. Plant Pathol. 2008, 123, 111-116. [CrossRef]

93. Matsushita, Y.; Usugi, T.; Tsuda, S. Distribution of tomato chlorotic dwarf viroid in floral organs of tomato. Eur. J. Plant Pathol. 2011, 130, 441-447. [CrossRef]

94. Verhoeven, J.T.J.; Jansen, C.C.C.; Roenhorst, J.W.; Flores, R.; de la Penã, M. Pepper chat fruit viroid: Biological and molecular properties of a proposed new species of the genus Pospiviroid. Virus Res. 2009, 144, 209-214.

95. Wan Chow Wah, Y.F.; Symons, R.H. Transmission of viroids via grape seeds. J. Phytopathol. 1999, 147, $285-291$.

96. Wallace, J.M.; Drake, R.J. A high rate of seed transmission of avacado sun bloth virus from symptomless trees and the origin of such trees. Phytopathology 1962, 52, 237-241.

97. Desjardins, P.R.; Drake, R.J.; Atkins, E.L.; Bergh, O. Pollen transmission of Avacado Sunblotch Virus experimentally demonstrated. Calif. Agric. 1979, 33, 14-15.

98. Desjardins, P.R.; Drake, R.J.; Sasaki, P.J.; Atkins, E.L.; Bergh, O. Pollen transmission of avocado sunblotch viroid and the fate of the pollen recipient tree. Phytopathology 1984, 74, 845.

99. Howell, W.; Skrzeczkowski, L.; Mink, G.; Nunez, A.; Wessels, T. Non-transmission of apple scar skin viroid and peach latent mosaic viroid through seed. Acta Hortic. 1998, 472, 635-640. [CrossRef]

100. Flores, R.; Hernández, C.; Avinent, L.; Hermoso, A.; Llácer, G.; Juárez, J.; Arregui, L.; Navarro Desvignes, J.C. Studies of the detection, transmission and distribution of Peach latent mosaic viroid (PLMVd) in peach trees. Acta Hortic. 1992, 309, 325-330.

101. Barba, M.; Ragozzino, E.; Faggioli, F. Pollen transmission of peach latent mosaic viroid. J. Plant Pathol. 2007, 89, $287-289$.

102. Fadda, Z.; Daros, J.A.; Fagoaga, C.; Flores, R.; Duran-Vila, N. Eggplant latent viroid, the candidate type species for a new genus within the family Avsunviroidae (hammerhead viroids). J. Virol. 2003, 77, 6528-6532.

103. Fagoaga, C.; Duran-Vila, N. Eggplant Latent; CSIRO Publishing: Collingwood, VIC, Australia, 2003.

104. Hammond, R.W. Seed, pollen, and insect transmission of viroids. In Viroids and Satellites; Academic Press: Cambridge, MA, USA, 2017; pp. 521-530.

105. Schumann, G.L.; Tingey, W.M.; Thurston, H.D. Evaluation of six insect pests for transmission of potato spindle tuber viroid. Am. J. Potato Res. 1980, 57, 205-211. [CrossRef]

106. Querci, M.; Lazarte, V.; Bartolini, I.; Salazar, L.F.; Owens, R.A. Evidence for heterologous encapsidation of potato spindle tuber viroid in particles of potato leafroll virus. J. Gen. Virol. 1997, 78, 1207-1211. [CrossRef]

107. Salazar, L.F.; Querci, M.; Bartolini, I.; Lazarte, V. Aphid transmission of potato spindle tuber viroid assisted by potato leafroll virus. Fitopatologia 1995, 30, 56-58.

108. Syller, J.; Marczewski, W.; Pawłowicz, J. Transmission by aphids of potato spindle tuber viroid encapsidated by potato leafroll luteovirus particles. Eur. J. Plant Pathol. 1997, 103, 285-289. [CrossRef]

109. Walia, Y.; Dhir, S.; Zaidi, A.A.; Hallan, V. Apple scar skin viroid naked RNA is actively transmitted by the whitefly Trialeurodes vaporariorum. RNA Biol. 2015, 12, 1131-1138. [CrossRef] 
110. Hidding, H.J.; Grum, C.J.; Hu, J.; Roth, D.A. Viroid-induced phosphorylation of a host protein related to a dsRNA-dependent protein kinase. Science 1988, 241, 451-453.

111. Gross, H.J.; Liebl, U.; Alberty, H.; Krupp, G.; Domdey, H.; Ramm, K.; Sänger, H.L. A severe and a mild potato spindle tuber viroid isolate differ in three nucleotide exchanges only. Biosci. Rep. 1981, 1, 235-241.

112. Owens, R.A.; Steger, G.; Hu, Y.; Fels, A.; Hammond, R.W.; Riesner, D. RNA structural features responsible for potato spindle tuber viroid pathogenicity. Virology 1996, 222, 144-158. [CrossRef]

113. Cress, D.E.; Kiefer, M.C.; Owens, R.A. Construction of infectious potato spindle tuber viroid cDNA clones. Nucleic Acids Res. 1983, 11, 6821-6835. [CrossRef]

114. Qi, Y.; Ding, B. Inhibition of cell growth and shoot development by a specific nucleotide sequence in a noncoding viroid RNA. Plant Cell 2003, 15, 1360-1374. [CrossRef]

115. De la Peña, M.; Navarro, B.; Flores, R. Mapping the molecular determinant of pathogenicity in a hammerhead viroid: A tetraloop within the in vivo branched RNA conformation. Proc. Natl. Acad. Sci. USA 1999, 96, 9960-9965.

116. Malfitano, M.; Di Serio, F.; Covelli, L.; Ragozzino, A.; Hernández, C.; Flores, R. Peach latent mosaic viroid variants inducing peach calico (Extreme chlorosis) contain a characteristic insertion that is responsible for this symptomatology. Virology 2003, 313, 492-501.

117. Flores, R.; Owens, R.A.; Taylor, J. Pathogenesis by subviral agents: Viroids and hepatitis delta virus. Curr. Opin. Virol. 2016, 17, 87-94. [CrossRef]

118. Momma, T.; Takahashi, T. Cytopathology of shoot apical meristem of hop plants infected with hop stunt viroid. J. Phytopathol. 1983, 106, 272-280. [CrossRef]

119. Molnár, A.; Csorba, T.; Lakatos, L.; Várallyay, E.; Lacomme, C.; Burgyán, J. Plant virus-derived small interfering RNAs originate predominantly from highly structured single-stranded viral RNAs. J. Virol. 2005, 79, 7812-7818. [CrossRef]

120. Omarov, R.T.; Cioperlik, J.J.; Sholthof, H.B. RNAi-associated ssRNA-specific ribonucleases in Tombusvirus P19 mutant-infected plants and evidence for a discrete siRNA-containing effector complex. Proc. Natl. Acad. Sci. USA 2007, 104, 1714-1719.

121. Pantaleo, V.; Szittya, G.; Burgyán, J. Molecular bases of viral RNA targeting by viral small interfering RNA-programmed RISC. J. Virol. 2007, 81, 3797-3806.

122. Aregger, M.; Borah, B.K.; Seguin, J.; Rajeswaran, R.; Gubaeva, E.G.; Zvereva, A.S.; Windels, D.; Vazquez, F.; Blevins, T.; Farinelli, L.; et al. Primary and secondary siRNAs in geminivirus-induced gene silencing. PLoS Pathog. 2012, 8, e1002941.

123. Itaya, A.; Matsuda, Y.; Gonzales, R.A.; Nelson, R.S.; Ding, B. Potato spindle tuber viroid strains of different pathogenicity induces and suppresses expression of common and unique genes in infected tomato. Mol. Plant Microbe Interact. 2002, 15, 990-999. [CrossRef]

124. Owens, R.A.; Hammond, R.W. Viroid pathogenicity: One process, many faces. Viruses 2009, 1, 298-316. [CrossRef]

125. Wolff, P.; Gilz, R.; Schumacher, J.; Riesner, D. Complexes of viroids with histones and other proteins. Nucleic Acids Res. 1985, 13, 355-367. [CrossRef]

126. Henriquez, A.C.; Sänger, H.L. Purification and partial characterization of the major "pathogenesis-related" tomato leaf protein P14 from potato spindle tuber viroid (PSTV)-infected tomato leaves. Arch. Virol. 1984, 81, 263-284.

127. Goodman, T.C.; Nagel-Steger, L.; Rappold, W.; Klotz, G.; Riesner, D. Viroid replication: Equilibrium association constant and comparative activity measurements for the viroid-polymerase interaction. Nucleic Acids Res. 1984, 12, 6231-6246. [CrossRef]

128. De Alba, A.E.M.; Sägesser, R.; Tabler, M.; Tsagris, M. A Bromodomain-containing protein from tomato specifically binds potato spindle tuber viroid rna in vitro and in vivo. J. Virol. 2003, 77, 9685-9694. [CrossRef]

129. Maniataki, E.; Tabler, M.; Tsagris, M. Viroid RNA systemic spread may depend on the interaction of a 71-nucleotide bulged hairpin with the host protein VirP1. RNA 2003, 9, 346-354. [CrossRef]

130. Diener, T.; Hammond, R.; Black, T.; Katze, M. Mechanism of viroid pathogenesis: Differential activation of the interferon-induced, double-stranded RNA-activated, Mr 68000 protein kinase by viroid strains of varying pathogenicity. Biochimie 1993, 75, 533-538. [CrossRef]

131. Langland, J.O.; Jin, S.; Jacobs, B.L.; Roth, D.A. Identification of a plant-encoded analog of PKR, the mammalian double-stranded RNA-dependent protein kinase. Plant Physiol. 1995, 108, 1259-1267. [CrossRef]

132. Hammond, R.W.; Zhao, Y. Characterization of a tomato protein kinase gene induced by infection by potato spindle tuber viroid. Mol. Plant Microbe Interact. 2000, 13, 903-910. [CrossRef]

133. Kolonko, N.; Bannach, O.; Aschermann, K.; Hu, K.-H.; Moors, M.; Schmitz, M.; Steger, G.; Riesner, D. Transcription of potato spindle tuber viroid by RNA polymerase II starts in the left terminal loop. Virology 2006, 347, 392-404. [CrossRef]

134. Eiras, M.; Nohales, M.A.; Kitajima, E.W.; Flores, R.; Daròs, J.A. Ribosomal protein L5 and transcription factor IIIA from Arabidopsis thaliana bind in vitro specifically Potato spindle tuber viroid RNA. Arch. Virol. 2010, 156, 529-533. [CrossRef]

135. Wang, Y.; Qu, J.; Ji, S.; Wallace, A.J.; Wu, J.; Li, Y.; Gopalan, V.; Ding, B. A land plant-specific transcription factor directly enhances transcription of a pathogenic noncoding RNA template by DNA-dependent RNA Polymerase II. Plant Cell 2016, 28, 1094-1107. [CrossRef]

136. Mudiyanselage, S.D.D.; Qu, J.; Tian, N.; Jiang, J.; Wang, Y. Potato spindle tuber viroid RNA-templated transcription: Factors and regulation. Viruses 2018, 10, 503. [CrossRef]

137. Jiang, J.; Smith, H.N.; Ren, D.; Mudiyanselage, S.D.D.; Dawe, A.L.; Wang, L.; Wang, Y. Potato spindle tuber viroid modulates its replication through a direct interaction with a splicing regulator. J. Virol. 2018, 92, e01004-18. [CrossRef] 
138. Gómez, G.; Pallás, V. Identification of an in vitro ribonucleoprotein complex between a viroid RNA and a phloem protein from cucumber plants. Mol. Plant Microbe Interact. 2001, 14, 910-913. [CrossRef]

139. Gómez, G.; Pallás, V. A Long-distance translocatable phloem protein from cucumber forms a ribonucleoprotein complex in vivo with hop stunt viroid RNA. J. Virol. 2004, 78, 10104-10110. [CrossRef]

140. Daròs, J.A.; Flores, R. A chloroplast protein binds a viroid RNA In Vivo and facilitates its hammerhead-mediated self-cleavage. EMBO J. 2002, 21, 749-759. [CrossRef]

141. Lisón, P.; Tárraga, S.; López-Gresa, P.; Saurí, A.; Torres, C.; Campos, L.; Bellés, J.M.; Conejero, V.; Rodrigo, I. A noncoding plant pathogen provokes both transcriptional and posttranscriptional alterations in tomato. Proteomics 2013, 13, 833-844. [CrossRef]

142. Vera, P.; Conejero, V. Citrus exocortis viroid infection alters the in vitro pattern of protein phosphorylation of tomato leaf proteins. Mol. Plant Microbe Interact. 1990, 3, 28-32.

143. Cottilli, P.; Belda-Palazón, B.; Adkar-Purushothama, C.R.; Perreault, J.-P.; Schleiff, E.; Rodrigo, I.; Ferrando, A.; Rubio, C. Citrus exocortis viroid causes ribosomal stress in tomato plants. Nucleic Acids Res. 2019, 47, 8649-8661. [CrossRef]

144. Dubé, A.; Bisaillon, M.; Perreault, J.-P. Identification of proteins from Prunus persica that interact with peach latent mosaic viroid. J. Virol. 2009, 83, 12057-12067. [CrossRef]

145. Martinez, G.; Castellano, M.; Tortosa, M.; Pallas, V.; Gomez, G. A pathogenic non-coding RNA induces changes in dynamic DNA methylation of ribosomal RNA genes in host plants. Nucleic Acids Res. 2014, 42, 1553-1562. [CrossRef]

146. Adkar-Purushothama, C.R.; Iyer, P.S.; Perreault, J.-P. Potato spindle tuber viroid infection triggers degradation of chloride channel protein CLC-b-like and Ribosomal protein S3a-like mRNAs in tomato plants. Sci. Rep. 2017, 7, 1-12. [CrossRef]

147. Herranz, M.C.; Niehl, A.; Rosales, M.; Fiore, N.; Zamorano, A.; Granell, A.; Pallás, V. A remarkable synergistic effect at the transcriptomic level in peach fruits doubly infected by prunus necrotic ringspot virus and peach latent mosaic viroid. Virol. J. 2013, 10, 164. [CrossRef]

148. Itaya, A.; Zhong, X.; Bundschuh, R.; Qi, Y.; Wang, Y.; Takeda, R.; Harris, A.R.; Molina, C.; Nelson, R.S.; Ding, B. A Structured viroid RNA serves as a substrate for dicer-like cleavage to produce biologically active small RNAs but is resistant to RNA-induced silencing complex-mediated degradation. J. Virol. 2007, 81, 2980-2994. [CrossRef]

149. Itaya, A.; Folimonov, A.; Matsuda, Y.; Nelson, R.S.; Ding, B. Potato spindle tuber viroid as inducer of RNA silencing in infected tomato. Mol. Plant Microbe Interact. 2001, 14, 1332-1334. [CrossRef]

150. De Alba, A.E.M.; Flores, R.; Hernández, C. Two chloroplastic viroids induce the accumulation of small rnas associated with posttranscriptional gene silencing. J. Virol. 2002, 76, 13094-13096. [CrossRef]

151. Papaefthimiou, I.; Hamilton, A.; Denti, M.; Baulcombe, D.; Tsagris, M.; Tabler, M. Replicating potato spindle tuber viroid RNA is accompanied by short RNA fragments that are characteristic of post-transcriptional gene silencing. Nucleic Acids Res. 2001, 29, 2395-2400.

152. Bolduc, F.; Hoareau, C.; St-Pierre, P.; Perreault, J.-P. In-depth sequencing of the siRNAs associated with peach latent mosaic viroid infection. BMC Mol. Biol. 2010, 11, 16. [CrossRef]

153. Ivanova, D.; Milev, I.; Vachev, T.; Baev, V.; Yahubyan, G.; Minkov, G.; Gozmanova, M. Small RNA analysis of Potato Spindle Tuber Viroid infected Phelipanche ramosa. Plant Physiol. Biochem. 2014, 74, 276-282. [CrossRef]

154. Navarro, B.; Pantaleo, V.; Gisel, A.; Moxon, S.; Dalmay, T.; Bisztray, G.; Di Serio, F.; Burgyan, J. Deep sequencing of viroidderived small RNAs from grapevine provides new insights on the role of RNA silencing in plant-viroid interaction. PLoS ONE 2009, 4, e7686. [CrossRef]

155. Sano, T.; Matsuura, Y. Accumulation of short interfering RNAs characteristic of RNA silencing precedes recovery of tomato plants from severe symptoms of potato spindle tuber viroid infection. J. Gen. Plant Pathol. 2004, 70, 50-53. [CrossRef]

156. Tsushima, T.; Murakami, S.; Ito, H.; He, Y.-H.; Raj, A.P.C.; Sano, T. Molecular characterization of Potato spindle tuber viroid in dahlia. J. Gen. Plant Pathol. 2011, 77, 253-256. [CrossRef]

157. Wang, Y.; Shibuya, M.; Taneda, A.; Kurauchi, T.; Senda, M.; Owens, R.A.; Sano, T. Accumulation of Potato spindle tuber viroidspecific small RNAs is accompanied by specific changes in gene expression in two tomato cultivars. Virology 2011, 413, 72-83. [CrossRef]

158. Adkar-Purushothama, C.R.; Perreault, J.-P. Alterations of the viroid regions that interact with the host defense genes attenuate viroid infection in host plant. RNA Biol. 2018, 15, 955-966. [CrossRef]

159. Navarro, B.; Gisel, A.; Rodio, M.E.; Delgado, S.; Flores, R.; Di Serio, F. Small RNAs containing the pathogenic determinant of a chloroplast-replicating viroid guide the degradation of a host mRNA as predicted by RNA silencing. Plant J. 2012, 70, 991-1003. [CrossRef]

160. Adkar-Purushothama, C.R.; Sano, T.; Perreault, J.-P. Viroid-derived small RNA induces early flowering in tomato plants by RNA silencing. Mol. Plant Pathol. 2018, 19, 2446-2458. [CrossRef]

161. Aviña-Padilla, K.; Martinez de la Vega, O.; Rivera-Bustamante, R.; Martinez-Soriano, J.P.; Owens, R.A.; Hammond, R.W.; Vielle-Calzada, J.-P. In silico prediction and validation of potential gene targets for pospiviroid-derived small RNAs during tomato infection. Gene 2015, 564, 197-205.

162. Aviña-Padilla, K.; Rivera-Bustamante, R.; Kovalskaya, N.Y.; Hammond, R.W. Pospiviroid infection of tomato regulates the expression of genes involved in flower and fruit development. Viruses 2018, 10, 516. [CrossRef]

163. Di Serio, F.; DE Alba, A.E.M.; Navarro, B.; Gisel, A.; Flores, R. RNA-Dependent RNA polymerase 6 delays accumulation and precludes meristem invasion of a viroid that replicates in the nucleus. J. Virol. 2009, 84, 2477-2489. [CrossRef] 
164. Gómez, G.; Martínez, G.; Pallás, V. Viroid-induced symptoms in Nicotiana benthamiana plants are dependent on RDR6 activity. Plant Physiol. 2008, 148, 414-423. [CrossRef]

165. Schiebel, W.; Pélissier, T.; Riedel, L.; Thalmeir, S.; Schiebel, R.; Kempe, D.; Lottspeich, F.; Sänger, H.L.; Wassenegger, M. Isolation of an RNA-directed RNA polymerase-specific cDNA clone from tomato. Plant Cell 1998, 10, 2087-2101. [CrossRef]

166. Tsushima, D.; Adkar-Purushothama, C.R.; Taneda, A.; Sano, T. Changes in relative expression levels of viroid-specific small RNAs and microRNAs in tomato plants infected with severe and mild symptom-inducing isolates of Potato spindle tuber viroid. J. Gen. Plant Pathol. 2015, 81, 49-62. [CrossRef]

167. Owens, R.A.; Sano, T.; Duran-Vila, N. Plant viroids: Isolation, characterization/detection, and analysis. In Antiviral Resistance in Plants; Humana Press: Totowa, NJ, USA, 2012; pp. 253-271.

168. Hadidi, A.; Yang, X. Detection of pome fruit viroids by enzymatic cDNA amplification. J. Virol. Methods 1990, 30, $261-269$. [CrossRef]

169. Boonham, N.; González Pérez, L.; Mendez, M.S.; Lilia Peralta, E.; Blockley, A.; Walsh, K.; Barker, I.; Mumford, R.A. Development of a real-time RT-PCR assay for the detection of potato spindle tuber viroid. J. Virol. Methods 2004, 116, 139-146.

170. Shamloul, A.M.; Faggioli, F.; Keith, J.M.; Hadidi, A. A novel multiplex RT-PCR probe capture hybridization (RT-PCR-ELISA) for simultaneous detection of six viroids in four genera: Apscaviroid, hostuviroid, pelamoviroid, and pospiviroid. J. Virol. Methods 2002, 105, 115-121. [CrossRef]

171. Fukuta, S.; Nimi, Y.; Ohishi, K.; Yoshimura, Y.; Anai, N.; Hotta, M.; Fukaya, M.; Kato, T.; Oya, T.; Kanbe, M. Development of reverse transcription loop-mediated isothermal amplification (RT-LAMP) method for detection of two viruses and chrysanthemum stunt viroid. Annu. Rep. Kansai Plant Prot. Soc. 2005, 47, 31-36. [CrossRef]

172. Van Brunschot, S.L.; Bergervoet, J.H.W.; Pagendam, D.E.; De Weerdt, M.; Geering, A.D.W.; Drenth, A.; Van Der Vlugt, R. Development of a multiplexed bead-based suspension array for the detection and discrimination of pospiviroid plant pathogens. PLoS ONE 2014, 9, e84743. [CrossRef]

173. Ito, T.; Ieki, H.; Ozaki, K. Simultaneous detection of six citrus viroids and Apple stem grooving virus from citrus plants by multiplex reverse transcription polymerase chain reaction. J. Virol. Methods 2002, 106, 235-239. [CrossRef]

174. Levy, L.; Hadidi, A.; Garnsey, S.M. Reverse-transcription-polymerase chain reaction assays for the rapid detection of citrus viroids using multiplex primer sets. Proc. Int. Soc. Citric. 1992, 2, 800-803.

175. Boubourakas, I.N.; Voloudakis, A.E.; Fasseas, K.; Resnick, N.; Koltai, H.; Kyriakopoulou, P.E. Cellular localization of peach latent mosaic viroid in peach sections by liquid phase In Situ RT-PCR. Plant Pathol. 2010, 60, 468-473. [CrossRef]

176. Mumford, R.; Walsh, K.; Boonham, N. A comparison of molecular methods for the routine detection of viroids. EPPO Bull. 2000, 30, 431-435. [CrossRef]

177. Ragozzino, E.; Faggioli, F.; Barba, M. Development of a one tube-one step RT-PCR protocol for the detection of seven viroids in four genera: Apscaviroid, hostuviroid, pelamoviroid and pospiviroid. J. Virol. Methods 2004, 121, 25-29. [CrossRef]

178. Shamloul, A.; Hadidi, A.; Zhu, S.; Singh, R.; Sagredo, B. Sensitive detection of potato spindle tuber viroid using RT-PCR and identification of a viroid variant naturally infecting pepino plants. Can. J. Plant Pathol. 1997, 19, 89-96. [CrossRef]

179. Hajizadeh, M.; Navarro, B.; Bashir, N.S.; Torchetti, E.M.; Di Serio, F. Development and validation of a multiplex RT-PCR method for the simultaneous detection of five grapevine viroids. J. Virol. Methods 2012, 179, 62-69. [CrossRef]

180. Wang, X.; Zhou, C.; Tang, K.; Zhou, Y.; Li, Z. A rapid one-step multiplex RT-PCR assay for the simultaneous detection of five citrus viroids in China. Eur. J. Plant Pathol. 2008, 124, 175-180. [CrossRef]

181. Di Serio, F.; Malfitano, M.; Alioto, D.; Ragozzino, A.; Flores, R. Apple dimple fruit viroid: Sequence variability and its specific detection by multiplex fluorescent RT-PCR in the presence of apple scar skin viroid. J. Plant Pathol. 2002, 84, 27-34.

182. Shamloul, A.M.; Hadidi, A. Sensitive detection of potato spindle tuber and temperate fruit tree viroids by reverse transcriptionpolymerase chain reaction-probe capture hybridization. J. Virol. Methods 1999, 80, 145-155.

183. Botermans, M.; Van De Vossenberg, B.; Verhoeven, J.; Roenhorst, J.W.; Hooftman, M.; Dekter, R.; Meekes, E. Development and validation of a real-time RT-PCR assay for generic detection of pospiviroids. J. Virol. Methods 2013, 187, 43-50. [CrossRef]

184. Loconsole, G.; Onelge, N.; Yokomi, R.; Kubaa, R.A.; Savino, V.N.; Saponari, M. Rapid differentiation of citrus Hop stunt viroid variants by real-time RT-PCR and high resolution melting analysis. Mol. Cell. Probes 2013, 27, 221-229. [CrossRef]

185. Luigi, M.; Faggioli, F. Development of quantitative real-time RT-PCR for the detection and quantification of Peach latent mosaic viroid. Eur. J. Plant Pathol. 2011, 130, 109-116. [CrossRef]

186. Luigi, M.; Faggioli, F. Development of a quantitative Real-Time RT-PCR (qRT-PCR) for the detection of hop stunt viroid. Eur. J. Plant Pathol. 2013, 137, 231-235.

187. Nielsen, S.L.; Enkegaard, A.; Nicolaisen, M.; Kryger, P.; Marn, M.V.; Pleško, I.M.; Kahrer, A.; Gottsberger, R.A. No transmission of Potato spindle tuber viroid shown in experiments with thrips (Frankliniella occidentalis, Thrips tabaci), honey bees (Apis mellifera) and bumblebees (Bombus terrestris). Eur. J. Plant Pathol. 2012, 133, 505-509. [CrossRef]

188. Tessitori, M.; Rizza, S.; Reina, A.; Catara, A. Real-Time-PCR Based on SYBRGreen I for the Detection of Citrus Exocortis and Citrus Cachexia Diseases. 2005; pp. 456-459. Available online: https://escholarship.org/uc/item/7rh6k402 (accessed on 9 March 2021).

189. Nagamine, K.; Kuzuhara, Y.; Notomi, T. Isolation of single-stranded DNA from loop-mediated isothermal amplification products. Biochem. Biophys. Res. Commun. 2002, 290, 1195-1198. [CrossRef] 
190. Notomi, T.; Okayama, H.; Masubuchi, H.; Yonekawa, T.; Watanabe, K.; Amino, N.; Hase, T. Loop-mediated isothermal amplification of DNA. Nucleic Acids Res. 2000, 28, 63-73.

191. Park, J.; Jung, Y.; Kil, E.-J.; Kim, J.; Tran, D.T.; Choi, S.-K.; Yoon, J.-Y.; Cho, W.K.; Lee, S. Loop-mediated isothermal amplification for the rapid detection of Chrysanthemum chlorotic mottle viroid (CChMVd). J. Virol. Methods 2013, 193, 232-237. [CrossRef]

192. Thanarajoo, S.S.; Kong, L.L.; Kadir, J.; Lau, W.H.; Vadamalai, G. Detection of Coconut cadang-cadang viroid (CCCVd) in oil palm by reverse transcription loop-mediated isothermal amplification (RT-LAMP). J. Virol. Methods 2014, 202, 19-23. [CrossRef]

193. Boubourakas, I.; Fukuta, S.; Kyriakopoulou, P. Sensitive and rapid detection of peach latent mosaic viroid by the reverse transcription loop-mediated isothermal amplification. J. Virol. Methods 2009, 160, 63-68. [CrossRef]

194. Tsutsumi, N.; Yanagisawa, H.; Fujiwara, Y.; Ohara, T. Detection of potato spindle tuber viroid by reverse transcription loop mediated isothermal amplification. Res. Bull. Plant Prot. Serv. Jpn. 2010, 46, 61-67.

195. Soliman, H.; El-Matbouli, M. An inexpensive and rapid diagnostic method of Koi Herpesvirus (KHV) infection by loop-mediated isothermal amplification. Virol. J. 2005, 2, 83. [CrossRef]

196. Parida, M.; Sannarangaiah, S.; Dash, P.K.; Rao, P.V.L.; Morita, K. Loop mediated isothermal amplification (LAMP): A new generation of innovative gene amplification technique; perspectives in clinical diagnosis of infectious diseases. Rev. Med. Virol. 2008, 18, 407-421. [CrossRef]

197. Lee, S.H.; Ahn, G.; Kim, M.-S.; Jeong, O.-C.; Lee, J.H.; Kwon, H.G.; Kim, Y.-H.; Ahn, J.-Y. Poly-adenine-coupled LAMP barcoding to detect apple scar skin viroid. ACS Comb. Sci. 2018, 20, 472-481. [CrossRef]

198. Liu, X.-L.; Zhao, X.-T.; Muhammad, I.; Ge, B.-B.; Hong, B. Multiplex reverse transcription loop-mediated isothermal amplification for the simultaneous detection of CVB and CSVd in chrysanthemum. J. Virol. Methods 2014, 210, 26-31. [CrossRef]

199. Bhuvitarkorn, S.; Klinkong, S.; Reanwarakorn, K. Enhancing Columnea latent viroid detection using reverse transcription loop-mediated isothermal amplification (RT-LAMP). Int. J. Agric. Technol. 2019, 15, 215-228.

200. Tangkanchanapas, P.; Höfte, M.; De Jonghe, K. Reverse transcription loop-mediated isothermal amplification (RT-LAMP) designed for fast and sensitive on-site detection of pepper chat fruit viroid (PCFVd). J. Virol. Methods 2018, 259, 81-91. [CrossRef]

201. Panno, S.; Matíc, S.; Tiberini, A.; Caruso, A.G.; Bella, P.; Torta, L.; Stassi, R.; DavinoLoop, S. Loop mediated isothermal amplification: Principles and applications in plant virology. Plants 2020, 9, 46.

202. Tiberini, A.; Barba, M. Optimization and improvement of oligonucleotide microarray-based detection of tomato viruses and pospiviroids. J. Virol. Methods 2012, 185, 43-51. [CrossRef]

203. Zhang, Y.J.; Yin, J.; Jiang, D.M.; Xin, Y.Y.; Ding, F.; Deng, Z.N. A universal oligonucleotide microarray with a minimal number of probes for the detection and identification of viroids at the genus level. PLoS ONE 2013, 8, e64474.

204. Agindotan, B.; Perry, K.L. Macroarray detection of eleven potato-infecting viruses and potato spindle tuber viroid. Plant Dis. 2008, 92, 730-740. [CrossRef]

205. Barba, M.; Hadidi, A. Application of next-generation sequencing technologies to viroids. In Viroids and Satellites; Hadidi, A., Flores, R., Randles, J.W., Palukaitis, P., Eds.; Academic Press: Boston, MA, USA, 2017; Chapter 38; pp. 401-412.

206. Ito, T.; Suzaki, K.; Nakano, M.; Sato, A. Characterization of a new apscaviroid from American persimmon. Arch. Virol. 2013, 158, 2629-2631. [CrossRef]

207. Chiumenti, M.; Torchetti, E.; Di Serio, F.; Minafra, A. Identification and characterization of a viroid resembling apple dimple fruit viroid in fig (Ficus carica L.) by next generation sequencing of small RNAs. Virus Res. 2014, 188, 54-59. [CrossRef]

208. Jakše, J.; Radišek, S.; Pokorn, T.; Matousek, J.; Javornik, B. Deep-sequencing revealed Citrus bark cracking viroid (CBCVd) as a highly aggressive pathogen on hop. Plant Pathol. 2015, 64, 831-842. [CrossRef]

209. Wang, Y.; Atta, S.; Wang, X.; Yang, F.; Zhou, C.; Cao, M. Transcriptome sequencing reveals novel Citrus bark cracking viroid (CBCVd) variants from citrus and their molecular characterization. PLoS ONE 2018, 13, e0198022. [CrossRef]

210. Barba, M.; Hadidi, A. An overview of plant pathology and application of next-generation sequencing technologies. $C A B$ Rev. 2015, 10, 1-21.

211. Barba, M.; Czosnek, H.; Hadidi, A. Historical perspective, development and applications of next-generation sequencing in plant virology. Viruses 2014, 6, 106-136. [CrossRef]

212. Hadidi, A.; Barba, M. Next-generation sequencing: Historical perspective and current applications in plant virology. Petria 2012, 22, 262-277.

213. Hadidi, A.; Flores, R.; Candresse, T.; Barba, M. Next-generation sequencing and genome editing in plant virology. Front. Microbiol. 2016, 7, 1325. [CrossRef]

214. Abudayyeh, O.O.; Gootenberg, J.S.; Konermann, S.M.; Joung, J.; Slaymaker, I.M.; Cox, D.B.T.; Shmakov, S.; Makarova, K.S.; Semenova, E.; Minakhin, L.; et al. C2c2 is a single-component programmable RNA-guided RNA-targeting CRISPR effector. Science 2016, 353, aaf5573. [CrossRef]

215. Doudna, J.A.; Charpentier, E. The new frontier of genome engineering with CRISPR-Cas9. Science 2014, 346, 1258096. [CrossRef]

216. O'Connell, M.R.; Oakes, B.L.; Sternberg, S.H.; East-Seletsky, A.; Kaplan, M.; Doudna, J.A. Programmable RNA recognition and cleavage by CRISPR/Cas9. Nature 2014, 516, 263-266. [CrossRef]

217. Diener, T.O. Circular RNAs: Relics of precellular evolution? Proc. Natl. Acad. Sci. USA 1989, 86, 9370-9374.

218. Duran-Vila, N.; Elena, S.F.; Daròs, J.-A.; Flores, R. Chapter 2-Structure and evolution of viroids. In Origin and Evolution of Viruses, 2nd ed.; Academic Press: London, UK, 2008; pp. 43-64.

219. Diener, T. Viroids: The smallest known agents of infectious disease. Annu. Rev. Microbiol. 1974, 28, 23-40. [CrossRef] 
220. Diener, T. Are viroids escaped introns? Proc. Natl. Acad. Sci. USA 1981, 78, 5014-5015.

221. Hadidi, A. Relationship of viroids and certain other plant pathogenic nucleic acids to group I and II introns. Plant Mol. Biol. 1986, 7, 129-142. [CrossRef]

222. Kiefer, M.C.; Owens, R.A.; Diener, T. Structural similarities between viroids and transposable genetic elements. Proc. Natl. Acad. Sci. USA 1983, 80, 6234-6238.

223. Diener, T.O. Origin and evolution of viroids and viroid-like satellite RNAs. Virus Genes 1995, 11, 119-131. [CrossRef]

224. Hull, R. Chapter 6 - Genome composition, organization, and expression. In Plant Virology, 5th ed.; Hull, R., Ed.; Academic Press: Boston, MA, USA, 2014; pp. 247-339.

225. Wassenegger, M.; Spieker, R.L.; Thalmeir, S.; Gast, F.-U.; Riedel, L.; Sänger, H.L. A single nucleotide substitution converts potato spindle tuber viroid (PSTVd) from a noninfectious to an infectious RNA for nicotiana tabacum. Virology 1996, 226, 191-197. [CrossRef]

226. Wu, Q.; Ding, S.-W.; Zhang, Y.; Zhu, S. Identification of viruses and viroids by next-generation sequencing and homologydependent and homology-independent algorithms. Annu. Rev. Phytopathol. 2015, 53, 425-444. [CrossRef]

227. Moreno, M.; Vázquez, L.; López-Carrasco, A.; Martín-Gago, J.Á.; Flores, R.; Briones, C. Direct visualization of the native structure of viroid RNAs at single-molecule resolution by atomic force microscopy. RNA Biol. 2019, 16, 295-308. [CrossRef]

228. Legnini, I.; Di Timoteo, G.; Rossi, F.; Morlando, M.; Briganti, F.; Sthandier, O.; Fatica, A.; Santini, T.; Andronache, A.; Wade, M.; et al. Circ-ZNF609 is a circular RNA that can be translated and functions in myogenesis. Mol. Cell 2017, 66, 22-37.e9. [CrossRef] 